\title{
SOME COMMENTS ON THE ROLE OF DISCRETION IN MILITARY JUSTICE
}

\author{
ROBINSON O. EvERETT*
}

An unpopular war has produced vehement criticism of the military establishment; and military justice, a pillar of that establishment, has not been immune from that criticism. According to a book title, "Military Justice is to Justice as Military Music is to Music." From the more lofty position of the Supreme Court, Mr. Justice Douglas has referred to "so-called military justice" and to "the travesties of justice perpetrated un'der the 'Uniform Code of Military Justice." "2 Legislative proposals for reform of military justice have appeared from many quarters. ${ }^{3}$ And distrust of military justice has led to judicial constriction of court-martial jurisdiction.

Central to many of the complaints against military justice is the great discretion granted to military commanders in its administration. The following discussion has as its purpose the identification of the diverse areas in which discretion is a pivotal part of the military justice system. While the general approach here is descriptive, attention is given to newly emerging limitations on discretion in the military.

\section{I}

\section{Discretton of the Commander in Chite}

\section{A. Sources of Presidential Discretion}

\section{Article II of the Constitution}

Under Article II of the Constitution the President is vested with the "executive power" and is "Commander in Chief of the Army and Navy of the United States, and of the Militia of the several States, when called into the actual Service of the United States." It is unnecessary to decide to what extent these constitutional provisions would suffice of themselves to confer broad discretion upon the President in the administration of military justice, ${ }^{6}$ since Congress has delegated extensive

- Professor of Law, Duke University School of Law; Lt. Col., USAFR.

${ }^{1}$ R. Sherrili, Military Justice is to Justice as Military Music is to Music (ig6g).

${ }^{2}$ O'Callahan v. Parker, 395 U.S. 258, 266 ( 1969 ).

${ }^{3}$ E.g., Bayh, The Military Justice Act of 1971: The Need for Legislative Reform, ro AM. Crum. L. Rev. 9 (I97I); Sherman, Congressional Proposals for Reform of Military Law, to AM. CRIM. L. REv. 25 (1971); U.S. Court of Military Appeals and the Judge Advocates General, y97i ANnual Report I-2.

'O'Callahan v. Parker, 395 U.S. 258 (1969); Reid v. Covert, 354 U.S. I (I957); Toth v. Quarles, 350 U.S. II (1955); Latney v. Ignatius, 416 F.2d 82 I (D.C. Cir. I969).

¿U.S. ConsT. art. II, $\$ \$ \mathrm{I}, 2$.

${ }^{\circ}$ See Youngstown Sheet \& Tube Co. v. Sawyer, 343 U.S. 579 (1952). For an argument that the President has a very broad constitutional power to regulate military justice, see Fratcher, Presidential Power to Regulate Military Justice: A Critical Study of Decisions of the Court of Military Appeals, 34 N.Y.U.L. Rev. 86I (I959). 
power to the President. The scope of the power delegated depends, in part, on the basis for his exercise of military jurisdiction in a particular case.

\section{The Law of War}

One source of military jurisdiction is the law of war-a branch of international law. Thus, in Ex parte Quirin ${ }^{7}$ the Supreme Court permitted trial by military commission of eight spies who disembarked on the East Coast from German submarines during World War II. Even though one of the spies claimed American citizenship and the civil courts were available, the Court concluded that Congress had authorized such trial pursuant to its constitutional power "to define and punish Piracies and Felonies committed on the high Seas, and offenses against the Law of Nations.". By order, President Roosevelt had both appointed a military commission to try the accused and prescribed regulations governing the trial procedure and review of the case. The presidential order did not conform to the provisions of the Articles of War for trial an'd appellate review in courts-martial. ${ }^{\circ}$ Even so, the Court upheld the President's regulations. ${ }^{10}$

Similarly, the Supreme Court sustained the jurisdiction of a military commission which the Commanding General of the United States Army Forces, Western Pacific, appointed in 1945 to try General Yamashita for alleged war crimes in the Philippine Islands. ${ }^{11}$ Here again jurisdiction was predicated on the law of war and on Congress' constitutional power to define and punish offenses against the Law of Nations. Hostilities had terminated; but: a state of war continued, since peace had not yet been proclaimed. ${ }^{12}$ The regulation's prescribed by military authorities for Yamashita's trial permitted use of affidavits and depositions under circumstances when such evidence would not be admissible in a court-martial. However, in the Court's opinion the military establishment had been left free by Congress to use the rules of evidence it believed most appropriate. ${ }^{13}$

Courts created in connection with American military government of occupied Germany were considered by the Supreme Court in Madsen $v$. Kinsella. ${ }^{14}$ Mrs. Madsen, who was an American' citizen and the dependent wife of an Air Force lieutenant, was tried and found guilty of murder by a United States Military Government Court. This occupation court was deemed to be in the nature of a military commission, and its jurisdiction stemmed from the law of war. According to the

\footnotetext{
${ }^{7} 317$ U.S. I (1942).

${ }^{8}$ U.S. Const. art. I, $\$ 8$, d. ro.

3r7 U.S. at 22.

${ }^{10}$ Id. at 47. Some members of the Court considered that Congress did not intend the Articles of War to govern the procedures of a military commission convened by the President to determine questions relating to admitted enemy invaders. Other Justices concluded that although the trial was subject to whatever provisions of the Articles of War Congress had made applicable to "military commissions," the Articles cited by the defense counsel did not foreclose the procedures which the President preseribed or which the military commission was shown to have employed.

${ }^{11}$ In re Yamashita, 327 U.S. I (I946).

12 Id. at 12.

${ }^{13} I d$. at $18-23$.

${ }^{14} 343$ U.S. 34 I (1952).
} 
Court, military commissions "have been called our common-law war courts. They have taken many forms and borne many names. Neither their procedure nor their jurisdiction has been prescribed by statute."15 With respect to military commissions the Supreme Court also noted:

In the absence of attempts by Congress to limit the President's power, it appears that, as Commander-in-Chief of the Army and Navy of the United States, he may, in time of war, establish and prescribe the jurisdiction and procedure of military commissions, and of tribunals in the nature of such commissions, in territory occupied by Armed Forces of the United States. His authority to do this sometimes survives cessation of hostilities. ... The policy of Congress to refrain from legislating in this uncharted area does not imply its lack of power to legislate. That evident restraint contrasts with its traditional readiness to "make Rules for the Government and Regulation of the land and naval Forces; . . . " Under that clause Congress has enacted and repeatedly revised the Articles of War which have prescribed, with particularity, the jurisdiction and procedure of United States court-martial.16

The Court ruled that Article of War 15, as it then existed, provided a concurrent jurisdiction for courts-martial and military commissions with respect to violations. of the law of war; and military commanders had the discretion to choose which type of tribunal they would employ. ${ }^{17}$

In Quirin, Yamashita, and Madsen the Supreme Court was applying the law of war in connection with a declared war, and perhaps these decisions might be limited by that fact. ${ }^{18}$ However, in those situations where the law of war can properly be invoked, Congress has continued to provide military commanders "with a" choice between courts-martial, which are subject to the procedures and safeguards of the Uniform Code of Military Justice and the Manual for Courts-Martial, and military. commissions, for which the President as Commander-in-Chief and his subordinate commanders can make rules of evidence and provide for-trial procedure on an ad hoc basis.

Under Article I8 of the Uniform Code, general courts-martial "have jurisdiction to try any person who by the law of war is subject to trial by a military tribunal and may adjudge any punishment permitted by the law of war."19 Article ${ }^{2 I^{20}}$-in. wording almost identical to that of the corresponding Article of War I5 which was

${ }^{10}$ Id. at $346-47$.

${ }^{10}$ Id. at $348-49$ :

${ }^{27}$ Id. at 345-55. Cf. United States v. Schultz, I U.S.C.M.A. 512, 4 C.M.R. 104 (1952).

${ }^{18}$ Cf. United States v. Averette, I9 U:S.C.M.A. 363, 4I C.M.R. 363 (1970), discussed in 49 N.C.L. Rev. I88 (1970). There the Court of Military Appeals ruled that Article 2(10), which "in time of war" extends military jurisdiction to civilians "serving with or accompanying an armed force in the field," applied only in the event of a declared war. See. also Lee v. Madigan, 358 U.S. 228 (I959).

${ }^{10}$ Uniform Code of Military Justice, art. I8, 1o U.S.C. $\$ 818$ (1970) [hereinafter referred to as U.C.M.J.]. Since this express provision invoking the law of war appears only in the article concerning the jurisdiction of general courts-martial and is not contained in the comparable articles of the Uniform Code which deal with the jurisdiction of special and summary "courts-martial (U.C.M.J., arts". I 9 -20, Io U.S.C. $\$ \$ 8 x 9,820$ [1970]) there may arise a negative implication that special and summary courtsmartial were not intended to possess any jurisdiction under the law of war.

${ }^{20}$ U.C.M.J., art. 21 , 10 U.S.C. $\$ 821$ (1970). 
in effect at the time of Quirin and Yamashita ${ }^{21}$-provides that the jurisdiction of courts-martial does "not deprive military commissions, provost courts, or other military tribunals of concurrent jurisdiction with respect to offenders or offenses that by statute or by the law of war may be tried by" such courts. Under Article 36 the President may prescribe rules for the "procedure, including modes of proof, in cases before courts-martial, courts of inquiry, military commissions and other military tribunals."22 Refusal to appear or to testify "before a court-martial, military commission, court of inquiry or any other military court or board" is made punishable by Article 47 of the Code; ;3 $^{23}$ and a "court-martial, provost court, or military commission may punish for contempt any person who uses any menacing word, sign, or gesture in its presence or who disturbs its proceedings by any riot or disorder."24 Under certain circumstances the sworn testimony contained in the record of proceedings of a court of inquiry may "be read in evidence by any party before a courtmartial or military commission."25 Moreover, both Article $104,{ }^{20}$ which proscribes aiding the enemy, and Article 106, ${ }^{27}$ which concerns spies in time of war, authorize trial by court-martial or military commission. Each article clearly is based on the law of war; and unlike the other punitive articles of the Uniform Code, each applies to "any person" and not merely to persons subject to the Uniform Code. ${ }^{28}$

\section{Martial Law}

The broad discretion available to the Comman'der-in-Chief and his subordinates in dealing with offenses against the law of war-offenses for which even civilians can be tried by military tribunals-involves the atypical situation. Also atypical is the exercise of military jurisdiction pursuant to martial law, when civil courts cannot carry on their functions. ${ }^{29}$ Martial law is a doctrine of necessity; and if the necessity exists, the use of military personnel and military tribunals is permissible to maintain order. However, the imposition of martial law must have some basis in fact. ${ }^{30}$

\section{Congressional Delegation}

Military jurisdiction is usually based on the Uniform Code of Military Justice, ${ }^{31}$ which Congress enacted pursuant to its constitutional power "to make Rules for

\footnotetext{
21 See 327 U.S. at 19-20.

${ }^{22}$ U.C.M.J., art. 36 , 10 U.S.C. $\$ 836$ (1970). Similar wording was contained in Article of War 38 which was in effect when Quirin and Yamashita arose. Act of June 4, 1920, ch. 227, III, $\{x, 4 \mathrm{x}$ Stat. 794. Apparently it left the President free to provide quite different rules for military commissions than those which he preseribed to regulate trials by court-martial.

${ }^{28}$ U.C.M.J., art. 47, xo U.S.C. $\$ 847$ (1970).

22 U.C.M.J., art. 48 , ro U.S.C. $\$ 848$ (I970).

${ }^{25}$ U.C.M.J., art. 50, ro U.S.C. $\$ 850$ (I970).

${ }^{20}$ U.C.M.J., art. 104, To U.S.C. $\$ 904$ (1970).

${ }_{27}$ U.C.M.J., art. 106, 10 U.S.C. \$906 (x970).

${ }^{28}$ U.C.M.J., arts. 77-134, I0 U.S.C. $\$ \$ 877-934$ (1970).

${ }^{20}$ See Duncan v. Kahanamoku, 327 U.S. 304 (1946); Ex parte Milligan, 7r U.S. (4 Wall.) 2 (1866).

${ }^{30}$ Sterling v. Constantin, 287 U.S. 378 (I932).

31 The Code was originally enacted on May 5, r950, and was contained in ch. 169, 5 I (Arts. I-r 40 ), 64 Stat. 108-45. In 1956, it was recodified, $70 A$ Stat. 36-78, 10 U.S.C. $\$ \$ 801-940$ (1970).
} 
the Government and Regulation of the land and naval Forces."32 In Article 36 of the Code, Congress has made a broad delegation of power to the President in these terms:

(a) The procedure, including modes of proof, in cases before courts-martial, courts of inquiry, military commissions, and other military tribunals may be prescribed by the President by regulations which shall, so far as he considers practicable, apply the principles of law and the rules of evidence generally recognized in the trial of criminal cases in the United States district courts, but which may not be contrary to or inconsistent with this chapter.

(b) All rules and regulations made under this article shall be uniform insofar as practicable and shall be reported to Congress. ${ }^{33}$

In exercising this power delegated by Article $3^{6}$ and its predecessor statutory provisions, various Presidents have issued Executive Orders which prescribed Manuals for Courts-Martial. ${ }^{34}$ Similarly, from time to time Presidents have, in their discretion, amended a Manual for Courts-Martial by Executive Order. ${ }^{35}$ The term "modes of proof" that appears in Article $3^{6}$ might be interpreted to mean only rules of evidence. However, since the same article also uses the phrase "rules of evidence," it is arguable that "modes of proof" has a broader scope. And this probably has been the view of the military establishment. ${ }^{36}$

For decades, successive Manuals for Courts-Martial have contained discussions of the various punitive articles-first as they were in the Articles of War and more recently as the punitive articles appear in the Uniform Code. If "modes of proof," as used in Article 36 , is intended to include these discussions of the punitive articles,

\footnotetext{
${ }^{32}$ U.S. Const. art. I, $\$ 8$, cl. I4.

$U_{p}$ to this point the Supreme Court has refused to permit the Code's application to persons who were not members of the armed forces both at the time of the offense and the time of trial. Toth v. Quarles, 350 U.S. II (1955), held unconstitutional Article 3(a) of the Code, Io U.S.C. $\$ 803$ (a) (1970), insofar as it sought to retain military jurisdiction to try a former serviceman for offenses committed while he was on active duty. McElroy v. United States ex rel. Guagliardo, 36I U.S. 28I (x960); Wilson v. Bohlender, $36 x$ U.S. $28 \mathrm{I}$ (I960); Grisham v. Hagan, 36I U.S. 278 (I960); Kinsella v. United States ex. rel. Singleton, 361 U.S. 234 (1960); and Reid v. Covert, 354 U.S. I (1957), established that military jurisdiction does not extend to either civilian dependents or employees who accompany the armed forces overseas in time of peace. The Court has not yet expressly considered the constitutionality of Article 2(10), Io U.S.C. $\$ 802$ (10) (1970), which subjects to trial by court-martial civilians who accompany the armed forces in the field in time of war. See note 18, supra. Nor has the Court yet overruled its 1920 holding that discharged military prisoners may be amenable to military jurisdiction. Kahn v. Anderson, 255 U.S. I (1920).

${ }^{38}$ U.C.M.J., art. 36 , ro U.S.C. $\$ 836$ (I970). A predecessor of the article was enacted in I9x6 as part of the Articles of War, applicable to the Army. See Fratcher, supra note 6 , at 864 .

${ }^{36}$ Exec. Order No. II 476, 34 Fed. Reg. I0502 (I969) (prescribing the Manual for Courts-Martiar, United States [rev. ed. I969]); Exec. Order No. II430, 33 Fed. Reg. 13502 (I968) (prescribing the Manual for Courts-Martial, UNited States [xg69]); Exec. Order No. 10214, I6 Fed. Reg. I303 (195I). Pursuant to the Articles of War the President issued Manuals for Courts-Martial in I9I7, I92I, r928, and 1949, which were reported to Congress. Fratcher, supra note 6, at 865 .

${ }^{35}$ See, e.g., Exec. Order No. I0247, I6 Fed. Reg. 5035 (I95I) (suspending the limitations for violations. of Articles 82,85,86(3),87, 90, $9 \mathrm{I}(\mathrm{I})$ and (2), II 3 , and II5 of the U.C.M.J.); Exec. Order No. 10628, 20 Fed. Reg. $574 \mathrm{I}$ (I955) (restoring limitations upon punishments); Exec. Order No. 10565, I9 FED. Reg. 6299 (1954) (amending certain maximum punishments); Exec. Order No. 10652, 21 Fed. Reg. 235 (1956) (amending provisions concerning automatic reduction in certain sentences):

${ }^{20}$ The Court of Military Appeals has taken the position that "modes of proof" in Article 36 means only "rules of evidence." United States v. Worley, I9 U.S.C.M.A: 444, 445, 42 C.M.R. 46, 47 (1970).
} 
then the President has been delegated some discretion to choose between competing rules of substantive criminal law concerning the offenses proscribed in those articles.

Since the Constitution confers on Congress, not the President, an express power "to make Rules for the Government and Regulation of the land and naval Forces," a question arises as to Congress' right to delegate this power to the President. In several instances the question has been rendered moot by judicial rulings that the Manual's discussion of a particular offense was contrary to the legislative intent revealed by the Uniform Code. ${ }^{37}$ Three different Manuals for Courts-Martial have been promulgated by Presidential Executive Order since enactment of the Uniform Code $^{38}$ As contemplated by Article 36 of the Code, Congress has been informed of the existence of these Manuals, which have remained relatively constant in their discussions of the various punitive articles. The failure of Congress to repudiate the Manual interpretations of those articles might be considered as implied ratification of the President's action, in which event it would be unnecessary to determine if the President had been properly delegated authority in the first instance to interpret the punitive articles.

This issue of presidential authority to participate in defining crimes is especially important with respect to two punitive articles which-as various critics have complaine $\mathrm{d}^{39}$-are especially sweeping in their terms. Article 133, which applies only to commissioned officers, cadets, and midshipmen, proscribes conduct unbecoming an officer and gentleman. ${ }^{40}$ Article 334 -codified under the heading "General Article"applies to all military personnel and prohibits "all disorders and neglects to the prejudice of good order and discipline in the armed forces, all conduct of a nature to bring discredit upon the armed forcës, and crimes and offenses not capital."41 Although the point has sometimes been misunderstood, ${ }^{42}$ the third category of mis-

\footnotetext{
${ }^{87}$ United States v. Horton, 9 U.S.C.M.A. 469, 26 C.M.R. 249 (r958) (larceny); United States v. Welker, 8 U.S.C.M.A. 647, 25 C.M.R. I5I (1958) (larceny); United States v. Johnson, 7 U.S.C.M.A. 488,22 C.M.R. 278 (I957) (unauthorized absence and desertion); United States v. Jenkins, 7 U.S.C.M.A. 26x, 22 C.M.R. 5I (r956) (fraudulent enlistment); United States v. Huff, 7 U.S.C.M.A. 247, 22 C.M.R. 37 (1956) (desertion); United States v. Rushlow, 2 U.S.C.M.A. 641, ro C.M.R. 139 (1953) (descrtion). These decisions are criticized in Fratcher, supra note 6, at $87 \mathrm{r}-78$.

${ }^{38}$ In I95I, by President Truman; in 1968 , by President Johnson; and in 1969, by President Nixon. See note 34, supra.

${ }^{39}$ See, e.g., O'Callahain v. Parker, 395 U.S. 258, 265-66 (1969); Gaynor, Prejudicial and Discreditable Military Conduct: A Critical Appraisal of the General Article, 22 HAsT. L.J. 259 (I97I). But see Wiener, Are the General Military Articles Unconstitutionally Vague?, 54 A.B.A.J. 357 (1968). For a criticism of some of the applications of Article 134, see Everett, Article 134, Uniform Code of Military justice-A Study in Vagueness, 37 N.C.I. REv. I42 (I959). The I97I Annual Report of the Court of Military Appeals and the Judge Advocates General proposed that Congress consider legislation to "restrict the scope of Article 134 by enacting separate punitive articles of the code covering selected offenses now dealt with by Article 134, and by limiting the maximum punishment for other conduct prejudicial to good order and discipline or service-discrediting conduct to confinement and forfeitures for 6 months." I97I ANNUAL REPORT, supra note 3, at 2.

${ }^{40}$ U.C.M.J., art. I33, to U.S.C. $\$ 933$ (1970).

${ }^{11}$ U.C.M.J., art. I34, ro U.S.C. $\$ 934$ (1970).

18 A Senate Report erroneously assumed that a violation of the law of a foreign country would automatically constitute a violation of the Uniform Code. See.R. EverETt, MiLITARY JUstice IN THE ARMed Forces of the United States 4 I (1956).
} 
conduct-"crimes and offenses not capital"-is deemed to incorporate by reference conduct which would constitute a violation of criminal provisions of federal statutes other than the Uniform Code itself. ${ }^{43}$ As to this category the President has no opportunity to participate in defining the crime.

On the other hand, the first two categories of misbehavior-disorder's and servicediscrediting conduct-are so inexact that they even raise the specter of unconstitutional vagueness. ${ }^{44}$ The Manual for Courts-Martial, prescribed by Presidential Executive Order, has been employed as a means for imparting greater specificity to these two broad statutory standards, as well as to the standard of "conduct unbecoming an officer and gentleman," which is utilized in Article I33. The specificity is obtained in two ways-first through the Manual discussion of the two punitive articles $^{45}$ and also by setting out in a Manual appendix form specifications indicating how various offenses should be alleged under Articles I33 and I34. ${ }^{46}$ In substance, then, various Presidents in promulgating different Manuals for Courts-Martial have made determinations of substantive law as to the types of conduct which should be punishable under the broad wording of these two punitive articles.

Up to this point Con'gress has not interfered overtly with the President's prerogative in this regard; indeed, in enacting the Uniform Code in I950 and the Military Justice Act of $\mathrm{I} 968$, ${ }^{47}$ that body revealed no desife to change the use of Articles I33 and I34. On the other hand, the Court of Military Appeals, while sometimes permitting extensions of these two articles, ${ }^{48}$ developed a doctrine of preemption to the effect that Article I34 may not be employed to punish areas of conduct which were the subject of other punitive articles in the Uniform Code. ${ }^{49}$

Article 92 of the Uniform Code makes punishable the failure to obey "any lawful general order or regulation." As Commander-in-Chief the President may himself 1ssue such an order or regulation, or he may direct that it be issued by one of his subordinate commanders. By promulgating orders an'd regulations, the President may add substantially to those rules which military personnel may disobey only at their peril. In a sense, Article 92 delegates to the President and other military commanders a part of Congress' constitutional power to "make Rules for the Government and Regulation of the lan'd and naval Forces."

Article $3^{6}$ directs the President to apply, "so far as he considers practicable," the

\footnotetext{
${ }^{2}$ Manual for Courts-Martial, United States (rev. ed. 1969), I 213e [hereinafter cited as ManUAL].

"As to possible vagueness of Article 134, see United States v. Frantz, 2 U.S.C.M.A. I6I, 7 C.M.R.

37 (I953); Dynes v. Hoover, 6I U.S. (20 How.) 65 (I857); Everett, supra note 39:"

¿ Manuat, $19212,213$.

${ }^{10}$ Manuar, app. 6c. Forms I22-25 concern Article r33; forms 126-88 are for use-under Article I34.

¿7 Act of Oct. 24, I968, Pub. L. g0-632, 82 Stat. 1335-43.

${ }^{4}$ See, e.g., United States v. Hooper, 9 U.S.C.M.A. 637, 26 C.M.R. 4I7 (1958); United States v. Barry, 6 U.S.C.M.A. 609, 20 C.M.R. 325 (I956). See generally, Everett, supra note 39.

${ }^{\circ}$ United States v. Norris, 2 U.S.C.M.A. 236, 8 C.M.R. $3^{6}$ (1953); United States v. Johnson, 3 U.S.C.M.A. I74, II C.M.R. I74 (I953).

50 U.C.M.J., art. 92, 10 U.S.C. \$ 892 (1970).

${ }^{62}$ U.S. Const. art. I, $\S 8$, cl. İ 4 .
} 
rules of evidence used in the federal district courts. ${ }^{52}$ However, the President's determination of practicability seems nonreviewable, unless it clashes with a specific provision of the Uniform Code or the Constitution. Thus, the President was upheld in his choice of a rule governing corpus delicti-corroboration of confessions-which proved to be different from that utilized in the federal district courts and more favorable to the accused. ${ }^{53}$ It is illustrative of the President's discretion to amend Manual provisions that the 1969 edition of the Manual for Courts-Martial changed this rule of evidence governing corroboration to bring it into line with the federal practice $^{54}$ Ironically, in' dealing with self-incrimination, the Court of Military Appeals concluded that a Manual rule of evidence which later proved to be in accord with the federal rule ${ }^{55}$ was invalid because of conflict with provisions in the Uniform Code. ${ }^{56}$

The rules of character evidence prescribed by the President differ from those applied in many courts, since they permit proof of a person's character not only by testimony as to his reputation but also by testimony about the witness's own opinion of his character. ${ }^{57}$ No privilege is recognized by the Manual for Courts-Martial with respect to communications of a patient either to a military or a civilian physician. ${ }^{58}$ A certificate or statement concerning a comparison of fingerprints may be introduced in evidence without calling as a witness the person who made the comparison. ${ }^{59}$

For the military establishment one of the most helpful rules of evidence prescribed by the President in the Manual for Courts-Martial authorizes admission of official records as an exception to the hearsay rule. ${ }^{60}$ Proof of unauthorized absence-probably the offense most frequently tried by court-martial-is usually accomplished by introduction in evidence of official personnel records reflecting the absence. However, admissibility of an official record of a fact or event depends on the existence of an official duty to record that fact or event. ${ }^{61}$ The President as Commander-in-

\footnotetext{
${ }^{52}$ U.C.M.J., art. 36 , to U.S.C. $\$ 836$ (1970).

${ }^{58}$ United States v. Smith, I3 U.S.C.M.A. 105, 32 C.M.R. I05 (1962) (extensive discussion of power delegated to the President under Article 36); United States v. Mims, 8 U.S.C.M.A. 3r6, 24 C.M.R. I26 (1957); United States v. Villasenor, 6 U.S.C.M.A. 3, I9 C.M.R. I29 (I955).

" Manual, If I $40 a(5)$. Similarly the Manual was changed in 1969 to allow presentencing consideration of nonjudicial punishments the accused received. Manuar, II $75 c(4)$. See United States v. Worley, 19 U.S.C.M.A. 444, 42 C.M.R. 46 (1970); United States v. Johnson, 19 U.S.C.M.A. 464,42 C.M.R. 66 (I970).

${ }^{85}$ Gilbert v. California, 388 U.S. 263 (1967); United States v. Wade, 388 U.S. 218 (1967); Schmerber v. California, 384 U.S. 757 (1966).

${ }^{50}$ United States v. Musguire, 9 U.S.C.M.A. 67, 25 C.M.R. 329 (I958); United States v. Rosato, 3 U.S.C.M.A. I43, II C.M.R. 143 (I953); United States v. Eggers, 3 U.S.C.M.A. I9I, II C.M.R. I9I (I953); United States v. Greer, 3 U.S.C.M.A. 576, 13 C.M.R. I32 (1953).

${ }_{57}$ Manuar I $138 f(I)$. Proposed Federal Rule of Evidence $405(a)$ adopts the same view as the military rule. 93 S.Ct. 37 (I973).

${ }^{88}$ Manoar, I $1510(2)$. Proposed Federal Rule of Evidence 504 provides only for a psychotherapistpatient privilege and does not provide a privilege generally. 93 S.Ct. 55 (I973).

${ }^{20}$ Manual, $\mathbb{I}$ I $43 a(2)(f)$.

${ }^{\circ 0}$ MaNual, I 1446 .

${ }^{\circ 1}$ Id. See also United States v. Kitchen, 5 U.S.C.M.A. 541, I8 C.M.R. I65 (1955); United States
} 
Chief is empowered to impose duties to record various facts and events. By creating a duty to prepare a record, he makes that record admissible in evidence. On various occasions the power to chan'ge record-keeping requirements has been utilized by military commanders to facilitate proo. ${ }^{\circ}$ of certain offenses. ${ }^{62}$

A striking feature of the Uniform Code is the provision in most of its punitive articles that upon conviction an accused "shall be punished as a court-martial may direct." ${ }^{\text {"3 }}$ Since a few of the punitive articles state that the accused "shall be punsshed by death or such other punishment as a court-martial may direct," ${ }^{n 4}$ it would appear on their face that most of the punitive articles would permit imposition of life imprisonment. Congress, however, has specifically authorized the President to prescribe limits on the punishment for an offense; ${ }^{65}$ and undoubtedly it contemplated that such limits would be imposed by the President for many types of offenses. The Manual for Courts-Martial contains a detailed Table of Maximum Punishments; ${ }^{\circ 6}$ and so the President, rather than Congress, possesses the discretion to prescribe the maximum punishments imposable for most offenses. Furthermore, especially with respect to combat areas, a President has sometimes removed the limitations on maximum punishments for certain offenses. ${ }^{67}$ In that event, the maximum punishment reverts to confinement for life.

Although it would be unusual for him to do so, the President is empowered by the Uniform Code to convene a court-martial. ${ }^{68}$ His approval of certain sentences is required; ${ }^{69}$ he may commute sentences; ${ }^{70}$ he possesses a constitutional authority "to grant Reprieves and Pardons for Offenses against the United States" include violations of the Uniform Code of Military Justice. With the advice and consent of the Senate, the President appoints all "Officers of the United States"72 among them the officers of the military establishment and the civilian judges of the Court of Military Appeals.

\section{B. Practical and Legal Limitations of Presidential Discretion}

To complete the survey of the President's discretion with respect to military justice, some of the practical and legal limitations of that discretion should be men-

v. Bennett, 4 U.S.C.M.A. 309, 15 C.M.R. 309 (I954); United States v. Wilson, 4 U.S.C.M.A. 3, 5 C.M.R. 3 (1954).

${ }_{02}$ See United States v. Simone, 6 U.S.C.M.A. I46, I9 C.M.R. 272 (I955); United States v. Kitchen, 5 U.S.C.M.A. 54I, I8 C.M.R. I65 (1955).

${ }^{\circ 3}$ U.C.M.J., arts. 77-134, 10 U.S.C. $\$ \$ 877-934$ (1970).

os See U.C.M.J., arts. $85,90,94,99$, I00, I01, I02, I04, II3, II 8, I20, Io U.S.C. $\$ \$ 885,890,894$, 899, 900, 901, 902, 904, 913, 918, 920 (1970). Article 106, 10 U.S.C. $\$ 906$ (1970), which concerns spies, provides a mandatory death sentence.

of U.C.M.J., art. 56, 10 U.S.C. $\$ 856$ (I970). See also U.C.M.J., art. 36, 10 U.S.C. $\$ 836$ (1970).

oO Manual, II $127 b$.

${ }^{\circ 7}$ See, e.g., Exec. Order No. 10247, I6 Fed. Reg. 5035 (1951).

os U.C.M.J., arts. 22-24, Io U.S.C. \$\$ 822-24 (I970).

${ }^{\circ 0}$ Manual, IT 98, Iooc(2).

${ }^{70}$ MaNUal, f ro5a.

${ }^{71}$ U.S. CoNst, art. II, $\$ 2$.

${ }^{72}$ Id. 
tioned. For example, Congress may amend the Uniform Code and, in so doing, may set aside rules which the President in his discretion has provided in the Manual for Courts-Martial. Furthermore, even with respect to offenses against the law of war, Congress apparently would be perfectly free to impose limitations on the President's discretion-for example, his discretion to use military commissions rather than courts-martial. Congress' constitutional power over the military budget also serves as a powerful restraint on presidential discretion in all matters pertaining to the military establishment. ${ }^{73}$

Congress has well-staffed committees whose existence facilitates its efforts to impose reins on the Commander-in-Chief and his. military subordinates. In fact, the extensive inquiries made by the Seriate Subcommittee on Constitutional Rights into the rights of military personnel caused it to be likened to a military ombudsman, as that post exists in West Germany. ${ }^{74}$ To maintain its access to information, Congress has specifically prohibited any effort by the military establishment to restrict communication by service personnel with members of Congress. ${ }^{75}$

Judicial decisions have also limited the potential role of presidential discretion in the administration of military justice. Thus, the Court of Military Appeals has established that military personnel do possess constitutional rights. ${ }^{\text {70 }}$ Therefore, the President and his subordinate military commanders may not take action which denies those rights.

Furthermore, the Supreme Court has restricted military jurisdiction both as to persons and offenses. Ex-servicemen are not subject to court-martial for offenses prior to discharge..$^{77}$ And civilian dependents and employees also fall outside the scope of military jurisdiction. ${ }^{78}$ Of special importance is $O^{\prime}$ Callahan v. Parker, ${ }^{70}$ which held that even as to military personnel military jurisdiction was lacking over offenses that were not service-connected.

The full impact of $O^{\prime}$ Callahan remains unknown. For example, the concept of service-connection has not yet been fully clarified, although the Supreme Court has since ruled that an offense committed on a military post is service-connected. ${ }^{80}$ 'The opinion of the Court in O'Callahan placed great emphasis on the unavailability

\footnotetext{
${ }^{73}$ U.S. Const. art. I, $\$ .8$, cl. 12, I3.

't See Hearings on S. Res. 260 Before the Subcomm. on Constitutional Rights of the Senate Comm. on the Judiciary, 87th Cong., 2d Sess. 822 (1962) (testimony of Frank E.G. Weil) [hereinafter cited as 1962 Hearings].

${ }^{76}$ ro U.S.C. $\$ 1034$ (I970). See also United States v. Schmidt, I6 U.S.C.M.A. 57, 36 C.M.R. 213 (I966).

${ }^{70}$ The Court of Military Appeals is a court composed of three civilian judges appointed by the President with the advice and consent of the Senate and was provided for by Article 67 of the Uniform Code, ro U.S.C. $\$ 867$ ( 9970$)$. More than a decade ago it proclaimed that "the protections in the Bill of Rights, except those which are expressly or by necessary implication inapplicable, are available to members of our armed forces." United States v. Jacoby, II U.S.C.M.A. 428, 430, 29 C.M.R. 244, 246 (I960). See also United States v. Tempia, I6 U.S.C.M.A. 629, 37 C.M.R. 249 (I967).

77 Toth v. Quarles, 350 U.S. Ir (1955).

${ }^{78}$ See note 32 supra.

${ }^{79} 395$ U.S. 258 ( 1969 ).

${ }^{80}$ Relford v. Commandant, 40x U.S. 355 (197x).
} 
of the protections of jury trial and grand jury indictment in courts-martial..$^{81}$ In light of that rationale, it is unclear whether $O^{\prime}$ Callahan applies to offenses committed in other countries where jury trial and grand jury indictment are unavailable in the civil courts. ${ }^{82}$ Similarly, petty offenses have been' held not to fall within the rule of $O^{\prime}$ Callahan, since there is no constitutional right to jury trial or grand jury indictment for such crimes. ${ }^{83}$ Furthermore, a question remains as to whether O'Callahan would have reached a different result in time of war, declared or undeclared.

The opinion in O'Callahan was also concerned with the interpretation of Congress' constitutional power to "make Rules for the Government and Regulation of the land and naval Forces." absence of jury trial and grand jury indictment, Congress lacks the power to regulate the conduct of military personnel if that conduct is not service-connected. Under this view Congress is constitutionally powerless to prohibit the acts that were involved in the O'Callahan case. Even if there had been legislative provision for prosecution of such acts in a federal tribunal where jury trial and grand jury indictment were available, jurisdiction of the offense would be lacking because Congress has no authority to regulate conduct that is not service-connected. Of course, if Congress lacked such authority, it could not be delegated to the President or to military commanders by Congress; nor would the Commander-in-Chief and his subordinate commanders appear to possess such authority in their own right. Furthermore, even if the President issued military orders that all personnel should refrain from certain conduct, the existence of such orders would not establish that the conduct was service-connected. Otherwise, the military establishment would be free to evade $O^{\prime}$ Callahan by issuing orders which prohibited conduct that in itself was not service-connected, relying on the orders to establish service-connection of the prohibited conduct, and prosecuting for disobedience of the prohibitory orders. ${ }^{85}$ of course, if $O^{\prime}$ Callahan intended only to denounce the lack of jury trial and grand jury indictment as to conduct that is not service-connected, then an entirely different result would obtain. Congress could cure the defect by providing that misconduct of military personnel, if not service-connected, could nonetheless be prosecuted in a federal district court, where jury trial and grand jury indictment are available, Similarly, the President and his subordinate military commanders could be authorized to issue orders regulating conduct that lacked service-connection, and prosecutions for disobedience of these orders would also take place in the federal courts.

\footnotetext{
${ }^{81} 395$ U.S. at $26 \mathrm{r}, 273$.

89 The Court of Military Appeals has ruled that $O^{\prime}$ Callahan does not apply to offenses committed overseas. United States v. Keaton, 19 U.S.C.M.A. 64, 4I C.M.R. 64 (I969). See also Blumenfeld, CourtMartial Jurisdiction Over Civilian-Type Crimes, ro AM. CRIM. L. Rev. 5I, 72 (I97I); Everett, O'Callahan v. Parker-Milestone or Millstone in Military Justice?, I969 Duke L.J. 853, 890.

${ }^{83}$ United States v. Sharkey, I9 U.S.C.M.A. 26, 4 I C.M.R. 26 (I969); Blumenfeld, supra note 82, at 71 ; Everett, supra note 82 , at 893 .

84 U.S. CoNsT. art. I, $\$ 8$, cl. 14.

BE The Court of Military Appeals seems to have rejected the view that the giving of the order provides service-connection. United States v. Castro, I8 U.S.C.M.A. 598, 40 C.M.R. 3 Io (I969).
} 
In addition to restricting the jurisdiction of courts-martial, the courts have sometimes opened wider the doors for successful collateral attack on court-martial jurisdiction. ${ }^{86}$ The availability of added opportunities for successful collateral attack on military action also has a limiting practical effect on the discretion available to the President and his subordinate commanders in the administration of military justice.

\section{II}

\section{Military Discretion To Employ Alternatives To Triad By Court-Martial}

\section{A. Assignment of Duties}

In civilian life criminal prosecutions are not the only means whereby governmental authorities may seek to deter disapproved conduct. Revocation of a license to practice a profession, ${ }^{87}$ conduct a business, or operate a vehicle, ${ }^{88}$ as well as deportation of undesirable aliens, ${ }^{89}$ blacklisting of government contractors, ${ }^{00}$ and civil penalties $^{21}$ illustrate, but do not exhaust, the possibilities.

Similarly, military commanders have many alternatives to the use of trial by court-martial. The very authority to give orders and promulgate regulations-an authority fortified by severe criminal penalties for disobedience ${ }^{02}$ - provides the commander with an important disciplinary tool. He may order a subordinate to take, or not take, some action, and disobedience of the order could then be punished by courtmartial. Of course, if the order is given for the sole purpose of increasing the penalty for an offense which it is expected the recipient of the order will commit, then disobedience of the order is not punishable. ${ }^{03}$ Similarly, a commander may not order a subordinate to perform additional duties for punitive purposes without complying with the Uniform Code. ${ }^{94}$ However, the commander is free to

\footnotetext{
${ }^{88}$ See, e.g., Parisi v. Davidson, 405 U.S. 34 (1972); Kauffman v. Secretary of the Air Force, 415 F.2d 99I (D.C. Cir. I969); but see Noyd v. Bond, 393 U.S. 1048 (1969); United Statcs v. Augcnblick, 393 U.S. 348 (r969); Burns v. Wilson, 346 U.S. 137 (r953). The leading precedents are discussed in Weckstein, Federal Court Review of Courts-Martial Proceedings: A Delicate Balance of Individual Rights and Military Responsibilities, $54 \mathrm{MrL}$. L. REv. I (I97I); Everett, Collateral Attack on Court-Martial Convictions, II A.F. JAG L. REv. 399 (1969); Sherman, Iudicial Review of Military Determinations and the Exhaustion of Remedies Requirement, 55 VA. L. REv. 483 (1969). The courts have also proved more receptive to collateral attacks on military administrative action. Harmon v. Brucker, 355 U.S. 579 (1958); Everett, Military Administrative Discharges-The Pendulum Swings, I966 Duke L.J. 41, 67.

${ }^{87}$ For example, an attorney may be disbarred from practice of his profession. 7 AM. Jur. 2D Attorneys at Law $\$ \$ 12-72$ (1963).

${ }^{88}$ Suspension or revocation of a driver's license because of traffic convictions is a familiar part of motor vehicle codes. See, e.g., N.C. GeN. Stat. \$20-I6 (Supp. 1965).

${ }^{88}$ See 8 U.S.C. $\$$ I25I (1970).

${ }^{\circ 0}$ See, for example, 4I U.S.C. $\$ \S$ Io(b), 37, 276a(2) (a) (I970), authorizing the debarment of bidders who have violated the Davis-Bacon, Walsh-Healy, and Buy American Acts.

${ }^{91}$ Civil penalties often are authorized without regard to the results of criminal proccedings which arise from the same facts. Rex Trailer Co. v. United States, 350 U.S. I48 (1956); United States ex. rel. Marcus v. Hess, 317 U.S. 537 (1943); Helvering v. Mitchell, 303 U.S. 39 I (1938); Various Items v. United States, 282 U.S. 577 (193I).

${ }_{92}$ U.C.M.J., arts. $90-92$, Io U.S.C. $\$ \$ 890-92$ (1970); MANUaL, $\mathbb{1} 127 b$.

${ }^{95}$ Manual, I $169 b$.

o4 U.C.M.J., art. 13, I0 U.S.C. $\$ 813$ (I970).
} 
require performance of additional duties for training purposes, ${ }^{95}$ and misconduct on the part of a member of his organization may properly alert the commander to that member's need for additional training. Many onerous duties in the armed forcessuch as kitchen police-have either disappeared or become less prevalent. Other duties may vanish in the near future as part of the program to make the military service more attractive to prospective volunteers. Yet the residue of unpleasant chores still seems sufficient to provide commanders with an important disciplinary tool.

In combat areas the commander's discretion in assigning hazardous duties is coupled with frightening penalties for failure to perform the assignments. ${ }^{96} \mathrm{Com}$ manders in charge of confinement installations may use administrative segregation and close order drill to correct inmates. ${ }^{\mathbf{9 7}}$ And commanders generally have a broad administrative power to deny passes and leave to their personnel or to impose restrictions to specified areas or limits. ${ }^{98}$

While it is true that the Code limits the imposition of an order which imposes additional duties for punitive purposes, ${ }^{99}$ the order will enjoy the benefit of a presumption of legality. ${ }^{100}$ And, unless a commander is very ill-informed, proof that he intended his order as a punishment will be hard to come by, for he will usually have some other explanation for giving the order. Moreover, there is considerable judicial reluctance to undertake review of the assignments of military duties. $^{101}$ Thus, an order assigning extra duties or restricting the recipient to specified limits can be challenged only at considerable peril to the subordinate who disobeys the order.

\footnotetext{
${ }^{05}$ United States v. Trani, I U.S.C.M.A. 293, 3 C.M.R. 27 (1952).

${ }^{\circ 0}$ See U.C.M.J., art. 99, ro U.S.C. $\$ 899$ (1970).

${ }^{07}$ United States v. Phillips, 18 U.S.C.M.A. 230, 39 C.M.R. 230 (I969); United States v. Vaughan, 3 U.S.C.M.A. I21, II C.M.R. I2I (I953); United States v. Trani, I U.S.C.M.A. 293, 3 C.M.R. 27 (I952); but $c f$. United States v. Williams, Io U.S.C.M.A. 6I5, 28 C.M.R. I8I (I959); United States v. Bayhand, 6 U.S.C.M.A. 762, 2 I C.M.R. 84 (I956).

${ }^{D 8}$ Cf. United States v. Petroff-Tachomakoff, 5 U.S.C.M.A. 806, I9 C.M.R. 120 (1955); United States v. Tcague, 3 U.S.C.M.A. 317, 12 C.M.R. 73 (1953); but cf. United States v. Gentle, 16 U.S.C.M.A. 437, 37 C.M.R. 57 (I966); United States v. Haynes, I5 U.S.C.M.A. 122, 35 C.M.R. 94 (1964). See also Manuaz, 1 r28c.

${ }^{00}$ Article 13 of the U.C.M.J., xo U.S.C. $\$ 8 \mathrm{I}_{3}$ (1970), prohibits punishment before trial; and Article I5 of the Code, ro U.S.C. $\$ 815$ (1970), appears to provide the sole method for legally imposing nonjudicial punishment. Cf. United States v. Gentle, I6 U.S.C.M.A. 437, 37 C.M.R. 57 (I966); United States v. Haynes, I5 U.S.C.M.A. I22, 35 C.M.R. 94 (1964); United States v. Williams, Io U.S.C.M.A. 6I5, 28 C.M.R. I8I (I959); United States v. Bayhand, 6 U.S.C.M.A. 762, 2I C.M.R. 84 (I956). Moreover, an order may not be "given for the sole purpose of increasing the penalty for an offense which it is expected the accused may commit." Manual, $\mathbb{1} 169 b$.

${ }^{200}$ The Manual now provides that "an order requiring the performance of a military duty or act may be inferred to be lawful and it is disobeyed at the peril of the subordinate." Manua, $q$ I69b. The corresponding wording of the I95I Manual was that "an order requiring the performance of a military duty or act is presumed to be lawful and is disobeyed at the peril of the subordinate." ManUar FOR Courts-Martial, United States (I95I), I I69b. The full impact of the change from presumption to inference is not yet clear. Among the cases relying on the presumption of legality under the prior Manual wording are United States v. Coombs, 8 U.S.C.M.A. 749, 25 C.M.R. 253 (I958), and United States v. Trani, I U.S.C.M.A. 293, 3 C.M.R. 27 (1952).

${ }^{101}$ See, e.g., Orloff v. Willoughby, 345 U.S. 83 (1953).
} 


\section{B. Promotions}

Pay and assignments have a very direct relationship to rank. Accordingly, by means of their discretion in determining promotions, military commanders possess an important tool for controlling the conduct of their personnel. With respect to enlisted personnel, commanders have a very direct control over promotions. Moreover, under some circumstances administrative demotions for inefficiency may be ordered. Promotions of officers hinge on the decisions of selection boards, which consider the military records of the various officers eligible for promotion. However, the most relevant part of these records for promotion purposes are the various ratings which, pursuant to service regulations, are periodically given to officers by their superiors. Low ratings of an officer by his commander may preclude his promotion. Furthermore, having been passed over when eligible for promotion may lead to an officer's separation from the service. Thus, especially for a career officer, fear of a low rating from his commander may have a very inhibiting influence on his conduct, and a commander is free to exploit that fear for disciplinary purposes. ${ }^{102}$

\section{Administrative Discharges}

Often a commander's primary concern is to remove permanently from his unitand perhaps from the armed services-a serviceman who is suspected of serious or repeated misconduct or who is a sexual deviant or a drug addict. One avenue to this goal is by preferring criminal charges, referring them to a court-martial for trial, and seeking a sentence which includes punitive discharge-a bad conduct discharge if the accused is tried by special court-martial or either a dishonorable or bad conduct discharge if he is tried by general court-martial. ${ }^{103}$ If, however, such a discharge is adjudged, then the Uniform Code provides for extensive and rather time-consuming appellate review. Furthermore, the safeguards provided to the accused by the Code -such as the presence of a military judge and trained defense counsel, rules of evidence, and proof of guilt beyond reasonable doubt-may prevent the court-martial's returning a finding of guilty. However, a commander may have another means for separating undesirable personnel, since the Uniform Code does not apply directly to administrative discharges-discharges which do not result from the sentence of a court-martial. At the present time five kinds of discharge are in use: (I) honorable; (2) general-which is under honorable conditions but differs from an honorable

\footnotetext{
${ }^{102}$ There have occasionally been indications that low efficiency ratings may be used by superior military officers to "punish" defense counsel for distateful tactics. See, e.g., United States v. Kitchens, Iz U.S.C.M.A. 589, 592, \& n.3, 3I C.M.R. 175, I78, \& n.3 (r96I). Congress has now specifically prohibited the use of efficiency ratings to influence court-martial personnel. U.C.M.J., art. 37(b), so U.S.C. $\$ 837$ (b) (1970). Military personnel may seek to attack unfavorable efficiency ratings through the Board for Correction of Military Records, established in each military department under 10 U.S.C. \& I552 (1970).

${ }_{103}$ Articles 18 and 19 of the Uniform Code, xo U.S.C. \$8 818, 819 (1970), deal respectively with the jurisdiction of general and special courts-martial. Dismissal of an officer, which can only be adjudged by a general court-martial, is equivalent to a dishonorable discharge of enlisted personnel.
} 
discharge; (3) undesirable; (4) bad conduct; and (5) dishonorable. ${ }^{104}$ The first three kinds can only result from administrative action and are not considered to be punishment; the last two must be adjudged by a court-martial as punishment. Regardless of the theoretical difference between them, the bad conduct discharge and the undesirable discharge, which is administrative, have almost the same effects on benefits. Moreover, each carries considerable stigma for the recipient. ${ }^{105}$ And the administrative undesirable discharge may be based on an unfitness demonstrated by acts for which the perpetrator could be tried by court-martial. ${ }^{108}$

Thus, a military commander often finds that he has discretion to choose between two methods for achieving separation of a misbehaving serviceman-namely, trial

${ }^{104}$ See Everett, Military Administrative Discharges-The Pendulum Swings, I966 DukE L.J. 4I, 43. The Task Force on the Administration of Military Justice believes "that the administrative discharge has impacted to the detriment of minority group servicemen. In all services, black service members received in Fiscal Year I97I a lower proportion of honorable discharges and a higher proportion of general and undesirable discharges than whites of similar aptitude and education." I TASR FORCE ON the Administration of Military JUstice in the ARmed Forces, Report IO9 (1972) [hereinafter cited as TASK Force Report]. Accordingly,

half the members of the Task Force recommend that the present characterization of administrative discharges be eliminated. The other half believe that the honorable discharge should be retained, although some would accept a course of action that would retain the honorable discharge but substitute the furnishing of an uncoded certificate of service in all administrative separations not meriting an honorable discharge. A majority of the members of the Task Force believe that if the honorable discharge is eliminated, the manner in which that would be accomplished would require serious and intensive study and that, pending completion of such a study, uncoded certificates of service should be furnished in all separations not meriting an honorable discharge.

The procedure for processing service personnel for elimination "with other than an honorable discharge [should] be revised to:

a. Ensure that the prospective dischargee is fully advised as to the potential consequences of the receipt of a discharge other than an honorable discharge, with an accurate and realistic appraisal of the possibility that such a discharge would never be changed to a a discharge of a more creditable nature; and

b. Strengthen the administrative due process safeguards presently accorded in the administrative discharge system by:

(I) Requiring a legally-qualified officer to sit as a member of any administrative elimination board, ruling on all legal questions.

(2) Requiring that the serviceman consult with counsel at the outset of any processing for elimination.

(3) Giving the respondent a right to legal counsel furnished by the government throughout the proceedings.

(4) Providing for participation by legally-qualified officers in review procedures.

c. Provide to the extent practicable that the composition of administrative elimination boards be designed to include minority membership.

d. Provide for the conditional suspension of administrative discharges and a probationary period, including reassignment to a new unit, for persons recommended for an administrative discharge, requiring the discharge authority, when he does not suspend the discharge and place the serviceman on probation, to state in writing his reasons therefor.

Id. I $18-19$.

${ }^{105}$ Id. at 45 n.2r. Because of the stigma, the Task Force also recommended that the Defense Department encourage legislation and other appropriate means that would prohibit civilian employers' inquiries as to the character of a serviceman's or servicewoman's discharge from the service. One means suggested was that the Equal Employment Opportunity Commission declare such an inquiry to be a discriminatory practice. The Task Force also recommended exploring the feasibility of establishing a procedure of substituting an uncoded certificate of service after an appropriate period of time for those who have, in the past, been awarded other than honorable discharges. Id. at IIg.

don Id. at 45 . 
by court-martial, which sometimes proves lengthy and laborious, and undesirable discharge, issued administratively and thus not subject to the Uniform Code and its procedural safeguards. The methods are not mutually exclusive; and so a commander may court-martial an accused for his infractions and, if the court-martial does not adjudge a punitive discharge, apparently may initiate administrative action based on essentially the same misconduct. ${ }^{107}$

At one point the armed services apparently abused their discretion to choose between court-martial and administrative discharge. As the Court of Military Appeals noted in its annual report for I960:

The unusual increase in the use of the administrative discharge since the code became a fixture has led to the suspicion that the services were resorting to that means of circumventing the requirements of the code. The validity of that suspicion was confirmed by Maj. Gen. Reginald C. Harmon, then Judge Advocate General of the Air Force, at the annual meeting of the Judge Advocates Association held at Los Angeles, Calif., August 26, I958. He there declared that the tremendous increase in undesirable discharges by administrative proceedings was the result of efforts of military commanders to avoid the requirements of the Uniform Code. Although he acknowledged that men thereby affected were deprived of the protection afforded by the code, no action to curtail the practice was initiated. ${ }^{108}$

As I have discussed elsewhere, this discretion has now been considerably limited by regulations of the armed services themselves and by various judicial decisions. ${ }^{100}$ Furthermore, Senator Ervin, the Chairman of the Senate Subcommittee on Constitutional Rights, has for many years made legislative proposals to regulate more closely the issuance of administrative discharges. ${ }^{110}$ However, a considerable residue of discretion still remains with the commander to choose between court-martial, administrative discharge proceedings, or a combination of the two.

\section{Nonjudicial Punishment}

Up to this point the discussion has concerned a commander's discretion to take action which, although not labelled punitive, may have much the same effect as would punishment. However, a commander also has the discretion to initiate action which is designated punishment but does not utilize trial by court-martial. Under Article 15 of the Uniform Code and subject to any more restrictive departmental

${ }^{107}$ Id. at 78-80. A court-martial has a different burden of proof for the Government-namely, proof beyond reasonable doubt. However, it is arguable that failure of a court-martial to impose a punitive discharge should limit the authority of the Government to discharge administratively for what is basically the same misconduct.

${ }^{108}$ Quoted in 1962 Hearings 2.

100 In Harmon v. Brucker, 355 U.S. 579 (1958), the Supreme Court ruled that administrative discharges were judicially reviewable. Since then various cases have arisen which involved attacks on administrative discharge action. See Everett, supra note I04. Among the most fruitful grounds of attack has been failure by the armed services to follow their own regulations. See, e.g., Roberts v. Vanec, 343 F.2d 236 (D.C. Cir. I964); Murray v. United States, I54 Ct. Cl. I85 (I96r); Clackum v. United States, 296 F.2d 226 (Ct. Cl. 1960). Cf. Vitarelli v. Seaton, 359 U.S. 535 (1959).

${ }^{110}$ See Everett, stipra note I04, at 4T. 
regulations, "any commanding officer" may impose certain nonjudicial punishment. ${ }^{111}$ The maximum punishment imposable is to some extent related to the rank of the commander who imposes the punishment. For example, if it is imposed on an enlisted accused by an officer of the grade of at least major or lieutenant commander, then nonjudicial punishment may include up to thirty consecutive days of "correctional custody"; ${ }^{112}$ but otherwise it is limited to seven consecutive days.

An Air Force squadron commander or Army company commander would normally lack power to convene a court-martial of any type; thus, if he chooses not to utilize Article 15, or if the accused refuses to accept nonjudicial punishment, the unit commander must either drop the charges or refer them to a superior commander for consideration. The captain of a naval vessel not only may impose nonjudicial punishment but also is empowered to convene a summary or special court-martial to try the accused. The traditionally wide discretion belonging to the captain of a naval vessel is also reaffirmed in Article I5's provision that as to enlisted persons "attached to or embarked in a vessel," a commander may impose "confinement on bread and water or diminished rations for not more than three consecutive days." 113 Ironically, even a general court-martial is subject to this same limitation in adjudging the punishment of confinement on bread and water, which in the view of the Court of Military Appeals involves cruel and unusual punishment. ${ }^{114}$

Not only the rank of the commander imposing nonjudicial punishment but also

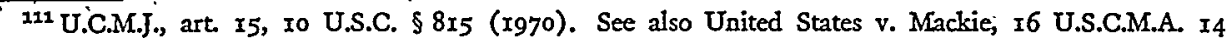
36 C.M.R. I70 (I966), which analogized Article I5 to the procedures available under I8 U.S.C. $\$ \$(3)$, 3401 (1970). The Task Force made a number of recommendations concerning nonjudicial punishment under Article 15-among them the following: nonjudicial punishment procedures be standardized among the services, insofar as practicable; servicemen be given the right to obtain the advice of legally-qualified military counsel before deciding whether to demand trial in lieu of nonjudicial punishment (except in those situations when the exigencies of the service limit the availability of counsel); an individual receive a personal hearing before the commander contemplating the imposition of punishment (except, again, when prevented by the exigencies of the service); a person at an Article 15 hearing have the right to be accompanied by an available personal representative- who may but need not be a lawyer-to advise him and to make a statement on his behalf; all Article I5 hearings be open to spectators, except where security interests dictate otherwise, but that the individual have the right to confer privately with the commander imposing punishment, to relate matters of a personal nature; when there are controverted questions of fact, witnesses be called if present on the same ship, post, or otherwise available; forfeitures and reduction not be imposed at a single Article $I_{5}$ action since both carry a loss of income; commanders take into consideration the effect which any monetary loss will have upon the offender or his family; commanders who impose a reduction in grade upon a first offender as a part of nonjudicial punishment, and who do not suspend that reduction, state for the record their reasons for not doing so; the increased use of correctional custody as a form of nonjudicial punishment be encouraged, with the necessary funding for manpower and facilities being provided; punishment under Article I5 $_{5}$ be stayed upon the filing of an appeal, provided the appeal is made at the time of imposition of punishment or within a reasonable time thereafter; every person receiving nonjudicial punishment be properly advised of his right to appeal; the length of time an Article I5 conviction remains in an individual's field personnel file be standardized; periodic monitoring of the administration of nonjudicial punishment be provided. TASR FoRCE REPORT I20-2r. In January, I973, many of these recommendations were administratively implemented by Secretary of Defense Laird.

112 "Correctional custody" is defined in Mandar, I r3Ic(4).

${ }^{228}$ U.C.M.J., art I5(b) (2) (A), Io U.S.C. $\$ 8 \mathrm{I}_{5}$ (b)(2)(A) (1970).

116 United States v. Wappler, 2 U.S.C.M.A. 393, 9 C.M.R. 23 (1953). 
the rank or grade of the accused affects the maximum punishment imposable. An officer is subject to entirely different nonjudicial punishments than those which a commander may impose on enlisted personnel. ${ }^{115}$ Further, an enlisted member in a pay grade above E-4 may not be reduced more than two pay grades. ${ }^{110}$

Although Article I5 provides for appeal from nonjudicial punishments, the greatest restraint on use of nonjudicial punishment is the option of an accused who has been offered such punishment to demand trial by court-martial. ${ }^{117}$ Until recently the case of an accused who rejected nonjudicial punishment might be referred to a summary court-martial for trial-where procedural protections are, at best, minimal-and he would have no right to refuse such trial. The Military Justice Act of $x 968$ created an absolute right to refuse trial by summary courtmartial-even if the accused had initially been offered nonjudicial punishment. ${ }^{118}$ Accordingly, in exercising his discretion in the first instance either to deal with an offense nonjudicially under Article I5 $_{5}$ or to prefer charges for trial by court-martial, a commander must consider the possibility that, even if initiated under Article 15, the case may, by the accused's exercise of his statutory rights, ultimately reach a special or general court-martial.

At one time it seemed arguable that if a case were initiated under Article 55 or by reference of charges to a summary court-martial but later was transferred to a special or general court-martial as a result of the accused's election not to receive nonjudicial punishment or not to be tried by summary court-martial, then the punishment imposable by the special or general court-martial should be limited to that which initially would have been imposable nonjudicially or by summary court-

${ }^{115}$ U.C.M.J., art. I5(b) (I), I0 U.S.C. $\$ 815$ (b)(I) (1970), as to officers; U.C.M.J., art. 15(b)(2), Io U.S.C. $\$ 8 \mathrm{r}_{5}(\mathrm{~b})(2)$ (1970), as to other personnel. An officer may not be subjected to correctional custody or confinement, demoted in grade, or assigned extra duties as nonjudicial punishment; under some circumstances such punishments may be imposed on enlisted personnel pursuant to Article 15.

${ }^{110}$ U.C.M.J., art. $\mathrm{I}_{5}(\mathrm{~b})(\mathrm{z})(\mathrm{H})(\mathrm{iv})$, ro U.S.C. \& $8 \mathrm{r}_{5}(\mathrm{~b})(\mathrm{z})(\mathrm{H})$ (iv) (1970). The power to demote depends on the promotion authority of the commander who is imposing nonjudicial punishment. See also U.C.M.J., art. I5 (b) (2)(D) (I970).

117 "[E]xcept in the case of a member attached to or embarked in a vessel, nonjudicial punishment may not be imposed upon any member of the armed forces if he has, before the imposition of such punishment, demanded trial by court-martial in lieu of such punishment." U.C.M.J., art. 15(a), 10 U.S.C. $\$ 815(a)$ (1970). As originally enacted, the Uniform Code did not grant a right to demand trial by court-martial in lieu of nonjudicial punishment, although it did grant the secretary of a department power, by regulation, to place limitations on the applicability of nonjudicial punishment to an accused who demands trial by court-martial. Pursuant to this provision, the Army and the Air Force granted an absolute right to demand trial by court-martial in lieu of nonjudicial punishment. The Navy and the Coast Guard gave no such right. Manual for Courts-Martiat, United States (195I), I 132. In I962, when the powers of a commander under Article 15 were strengthened, Congress also gave a statutory basis for the right to demand trial by court-martial except for personnel "attached to or embarked in a vessel." The current Manual follows the statutory wording. Manual, I 132.

${ }^{118}$ U.C.M.J., art. 20, to U.S.C. $\$ 820$ (1970). Previously an accused could object to trial by summary court-martial unless "he has been permitted and has elected to refuse punishment under Article 15." Manual for Courts-Martial, Untted States (195I), I 79d(r). Undoubtedly the right to object to nonjudicial punishment was significantly less valuable when the likelihood remained that the case could be referred to a summary court-martial and that the accused could not object to trial by that court-martial. This problem never existed for officers and warrant officers who have not been subject to trial by summary court-martial under the Uniform Code. U.C.M.J., art. 20, to U.S.C. $\$ 820$ (1970). 
martial. However, the recent Supreme Court ruling which upheld increased sentences after a de novo trial upon appeal from an inferior court would suggest a different result. ${ }^{119}$ Accordingly, an accused who declines nonjudicial punishment under Article 5 or elects not to be tried by a summary court-martial must reckon with the possibility that, when tried by a special or general court-martial, which has greater authority to punish, he may receive a sentence far greater than the maximum imposable either nonjudicially or by summary court-martial. Furthermore, in the instance of nonjudicial punishment, he does not carry the stigma of court conviction that would result from being found guilty by any kind of court-martial. ${ }^{120}$

\section{E. Trial by Civil Court}

Frequently a serviceman's conduct may involve not only violation of the Uniform Code but also of federal or state statutes or, if occurring overseas, the laws of a foreign country. In that instance, a military commander may have discretion to determine whether the accused is tried by a civil court, by a court-martial, or under some circumstances, by both. Within the United States, if military authorities institute court-martial proceedings, they are entitled to proceed and have no obligation to delay in order to permit trial in the civil courts. ${ }^{121}$ Conversely, if the jurisdiction of a state or federal civil court first attaches, it cannot be ousted by the commencement of court-martial proceedings. Trial by court-martial will preclude triali in a federal district court for the same offense, and vice versa. ${ }^{122}$ Whether a courtmartial creates double jeopardy with respect to trial in a state court, or the converse, seems more doubtful. ${ }^{123}$

Although American military authorities seem free under the Constitution to waive their jurisdiction over a serviceman in order to permit his trial by a foreign country, ${ }^{124}$ American policy does not favor such waivers. ${ }^{125}$ The NATO Status of

\footnotetext{
${ }^{110}$ Colten v. Kentucky, 407 U.S. I04 (1972).

${ }^{120}$ Contrary to the provisions under the I95I Manual, nonjudicial punishments may be considered by a court-martial in determining an appropriate sentence. MANUAI, I $75 d$. United States v. Johnson, 19 U.S.C.M.A. 464, 42 C.M.R. 66 (1970). However, it remains true that an "Article 15 punishment is not a conviction; it does not empower a court-martial to adjudge permissible additional punishments under Section B of the Table of Maximum Punishments." Id. at 467,42 C.M.R. at 69.

121 Concerning the relationship between courts-martial and civil courts, see R. EVERETr, supra note 42 , at $38-40$.

${ }^{122}$ Grafton v. United States, 206 U.S. 333 ( 1907 ).

${ }^{123}$ Bartkus v. Illinois, 359 U.S. I2I (I959); Abbate v. United States, 359 U.S. I87 (I959); United States v. Lanza, 260 U.S. 377 (I922); but cf. Murphy v. Waterfront Comm'n., 378 U.S. 52 (1964). Regardless of constitutional limitations, trial by court-martial for a crime for which the serviceman has already been tried in a state court is infrequent. 1962 Hearings $848,874,909,945,961$.

${ }^{124}$ Wilson v. Girard, 354 U.S. 524 (1957).

${ }^{125}$ Cf. J. Snee \& A. Pye, Status of Forces Agreement: Criminal Jurispiction in7-Ig (I957); R. Everert, supra note 42, at 44-45. With respect to the Status of Forces Agrcement, the Task Force recommended that when a case involves the exercise of jurisdiction by a foreign government a military advisor be provided to the accused, necessary action be taken to pay the accused who is in pretrial confinement, and all services be encouraged to use to the extent practicable a form of restraint other than pretrial confinement. TASK Force Report I26-27.
} 
Forces Agreement ${ }^{126}$ and other jurisdictional agreements modelled thereon ${ }^{12 t}$ prescribe very detailed rules concerning primary and secondary jurisdiction where the misconduct of a serviceman violates both the Uniform Code and the laws of the host country. ${ }^{128}$ Thus, they limit the military commander's discretion to choose between trial by court-martial and trial in the civil courts. Also, the Status of Forces Agreement provides a double jeopardy protection that seems unavailable to an accused who is tried both by court-martial and by state court. ${ }^{12 \theta}$

In determining whether to try by court-martial or to defer to trial in the civil courts, military commanders may be limited by agreements between the Defense Department and the Department of Justice ${ }^{130}$ and by local understandings with civil authorities. They may also be influenced by the circumstance that a serviceman who is convicted of a felony by a civil court may be administratively discharged as undesirable. ${ }^{131}$ Thus, trial and conviction of a serviceman in a civil court may provide an easy means for separating him from the armed services.

\section{F. Reserve Personnel}

If reserve personnel on extended active duty engage in conduct distasteful to their commanders, the result may be release from active duty. ${ }^{132}$ This discretion. to release from active duty may have serious financial consequences for the reservistespecially for the career reserve officer. Thus, a reservist may have a strong inducement to behave in the manner least likely to prompt a decision by his commander that he be returned to civilian life.

For reserve personnel not on active duty, the discretion of military commanders may be adversely exercised in just the opposite way-by action that will bring such personnel from civilian life into uniform. Sometimes a poorly performing reservist has been ordered to extended active duty pursuant to his obligations as a member of the reserve forces; in other instances, he has been dropped from his reserve

\footnotetext{
${ }^{126}$ NATO Status of Forces Agreement, June 19, I95I, art. VIII, [I953] 2 U.S.T. I792, T.I.A.S. No. 2846. See also Status of Forces Policies and Information, Department of Defense Directive No. 5525.I, Jan. 20, $x 966$.

${ }^{127}$ For example, an executive agreement of Oct. 29, 1953, with Japan, contained criminal jurisdictional provisions like those of the NATO Status of Forces Agreement. See [1953] 4 U.S.T. 1846, T.I.A.S. No. 2848. The agreement with West Germany modifies the jurisdictional scheme significantly. Supplementary Agreement to NATO Status of Forces Agreement for Federal Republic of Germany, Aug. 3, 1959, [1963] 14 U.S.T. 53I, T.I.A.S. No. 535 I (effective July 1 , 1963).

${ }^{228}$ Generally the host country will have primary jurisdiction unless the offense was committed in the performance of official duty or involved only the security or property of the sending state or the person or property of other nationals of the sending state. NATO Status of Forces Agrcement, art. ViII, ๆ3.

${ }^{120}$ NATO Status of Forces Agreement, art. VII, I 8. For cases involving this protection sce United States v. Cadenhead, I4 U.S.C.M.A. 27I, 34 C.M.R. 5 I (1963); United States v. Sinigar, 6 U.S.C.M.A. 330, 20 C.M.R. 46 (I955).

${ }_{180} 1962$ Hearings $847,909,945$.

181 See Everett, stipra note ro4, at 58.

${ }^{183}$ Sce, for example, Roberts v. Vance, 343 F.2d 236 (D.C. Cir. I964), where, however, the rclease from active duty of the reserve Army officer was set aside because the Army failed to abide by applicable Army regulations governing such releases.
} 
unit and thereby made subject to draft induction. Thus, one reservist was in danger of induction because he had not received credit for attending the training periods of his reserve unit. Under Army directives, credit was precluded since the reservist had appeared at such periods in long hair, which he claimed was necessitated by his employment as agent for "rock and roll" bands. Upholding the military establishment, a Court of Appeals observed that applicable statutes required reserve personnel to "satisfactorily participate in scheduled drills and training periods as prescribed by the Secretary of Defense"; and it concluded that, unless extraordinary circumstances existed, courts should not review a military determination that participation had been unsatisfactory. ${ }^{133}$ Existence of this administrative means to discipline reserve personnel not on active duty is all the more important because of severe limitations on military jurisdiction to try such personnel by court-martial. ${ }^{134}$

III

\section{Investigation and Pretrial Procedures}

\section{A. Searches and Seizures}

Although the Uniform Code does not purport to limit umreasonable searches and seizures, the Manual for Courts-Martial has long contained a prohibition against the reception of evidence obtained by an unreasonable search and seizure. ${ }^{135}$ However, the determination of what constitutes reasonableness still leaves considerable room for a commander's discretion to operate. At one time it was the position of the military establishment that searches on a military installation could be undertaken by authorization of a suitable commander without any showing of probable cause. The commander was analogized to a property-owner inspecting his own property. The Court of Military Appeals did not accept this view and has long required that probable cause exist even for a search on post. ${ }^{136}$ However, the military commander remains free to determine probable cause, rather than submit the facts to a neutral, detached magistrate. ${ }^{137}$ Nor has there been a requirement that an affidavit be prepared which would set forth the circumstances believed to establish probable cause. ${ }^{138}$

\footnotetext{
${ }^{18 s}$ Raderman v. Kaine, 4II F.2d Iro2 (2d Cir. I969), cert. denied 396 U.S. 976 (I969).

${ }^{184}$ See U.C.M.J., Article 2(3), Io U.S.C. $\$ 802$ (3) (I970), which restricts such jurisdiction to those reservists who have voluntarily accepted written orders specifying that they are subject to the Uniform Code of Military Justice. See also United States v. Schuering, I6 U.S.C.M.A. 324, 36 C.M.R. 480 (I966); but see Wallace v. Chafee, 45I F.2d 1374 (9th Cir. I97I).

${ }^{135}$ Manual, 1 I 52 . See also Manual for Courts-Martiar, United States (I95I), I 152.

${ }^{180}$ United States v. Brown, Io U.S.C.M.A. 482,28 C.M.R. 48 (1959).

107 As to the requirement of a neutral, detached magistrate, see Coolidge v. New Hampshire, 403 U.S. 443 (197I); Aguilar v. Texas, 378 U.S. I08 (I964); Giordenello v. United States, 357 U.S. 480 (I958):

${ }^{188}$ For applications of this requirement in the federal courts, see, e.g., Spinelli v. United States, 394 U.S. 4ro (I969); United States v. Ventresca, 380 U.S. I02 (I965). In United States v. Martinez, I6 U.S.C.M.A. 40, 36 C.M.R. 196 ( 1966 ), it is suggested that authority to search be in writing and set out the facts upon which the authorization is based and the articles to be seized. See also United States v. Penman, 16 U.S.C.M.A. 67, 69, 36 C.M.R. 223, 225 (I966). The Air Force seems to have accepted this suggestion. See AF Form $\mathrm{II}_{76} 6$ "Authority to Search and Seize."
} 
The Manual for Courts-Martial appears to allow "administrative inspections." In so doing, it has given greater legitimacy to the shakedown inspections so often used in the armed forces-inspections of a barracks or similar area to determine its cleanliness and the presence of contraband. ${ }^{140}$ These inspections provide an obvious tool for harassment, and they are hard to reconcile with the Supreme Court's emphasis on the need for court orders even in connection with health inspections. ${ }^{141}$ However, recently the Court has granted greater leeway for administrative inspections without court orders. ${ }^{142}$

The armed services have themselves begun to encourage the preparation of written statements of reasons for a search ${ }^{143}$-statements somewhat paralleling the affidavits used in civil courts for establishing probable cause. Also, the military judge is sometimes being utilized as a magistrate to determine whether probable cause exists. ${ }^{144}$ Just as warrants issued by a magistrate upon an affidavit are given greater weight than the determination of probable cause by a police officer, so too, the warrants for search issued by the military judges will probably fare better in the courts than determinations of probable cause made by a commander. It seems likely that control of authorizations to search will ultimately be concentrated in the hands of the military judiciary, in which event the courts may be more willing to decide borderline cases in favor of the Government.

\section{B. Apprehension and Confinement}

Apprehension-the military equivalent of arrest in civilian life ${ }^{\mathbf{1 4 5}}$-requires "reasonable belief that an offense has been committed and that the person apprehended committed it."146 However, the Code does not provide either for the issuance of arrest warrants or for preliminary hearings to determine if probable cause exists. Thus, the discretion of military authorities in taking a serviceman into custody as a suspect is virtually non-reviewable. ${ }^{147}$

\footnotetext{
${ }^{189}$ See MandaL, If 152 . After setting forth a restriction on permissible objects of search, the Manual provides that, "[ $t]$ his restriction does not apply to administrative inspections or inventories conducted in accordance with law, regulation, or custom." In the corresponding paragraph of the I951 Manual there is no reference to "administrative inspections," but an exception is recognized for the legality of searches made by military personnel "in accordance with military custom." MANUAL for CouRTs-MARTiAL, United States (I95r), I I52.

${ }^{140}$ The Court of Military Appeals has been willing to uphold "shakedown" inspections under some circumstances. United States v. Gebhart, to US.C.M.A. 606, 28 C.M.R. 172 (1959); United States v. Swanson, 3 U.S.C.M.A. $67 \mathrm{r}$, 14 C.M.R. 89 (r954). For a recent case holding that, under the particular facts, the shakedown was a search and not an inspection, see United States v. Lazerus, C.M. 426877 (Army Court of Military Review, Aug. 15, 1972).

${ }^{142}$ Camara v. Municipal Court, 387 U.S. 523 (I967); See v. Seattle, $3^{87}$ U.S. 541 (I967).

${ }^{142}$ Wyman v. James, 400 U.S. 309 (I97I).

${ }^{243}$ See note 138 , supra.

${ }^{146}$ The Army has empowered its military judges to issue search warrants. See 1971 ANNUAL Repont, supra note 3 , at 3,21 .

${ }^{145}$ In military justice, "arrest is the restraint of a person by an order, not imposed as punishment for an offense, directing him to remain within certain specified limits." MANUAL, If $18 a$.

${ }^{110}$ U.C.M.J., art. 7, ro U.S.C. $\$ 807$ (1970).

${ }^{147}$ If a search has been made incident to apprehension, the legality of the apprehension may be reviewed in determining the admissibility of evidence seized in connection therewith. See, e.g., United States v. Ball, 8 U.S.C.M.A. 25, 23 C.M.R. 249 (I957).
} 
Pretrial confinement of persons charged with offenses is authorized by the Uniform Code "as circumstances may require."148 The Manual for Courts-Martial limits this authority to situations where such confinement is "deemed necessary to insure the presence of the accused at the trial or because of the seriousness of the offense charged."149 The military's right to confine before trial because of the seriousness of the offense charged may go beyond the power of civil authorities. ${ }^{\mathbf{1 5 0}}$ Moreover, in civilian life bail is available so that an accused may obtain his release prior to trial, and an unreasonably high bail may be contested by appeal. ${ }^{151}$ In the military system of justice bail is not allowed, and judicial remedies are not readily available to contest an unreasonable denial of freedom pending trial. ${ }^{152}$ In some military commands, however, local regulations have been promulgated to prevent unnecessary pretrial confinement. ${ }^{153}$ Moreover, in civilian life there has been considerable criticism of reliance on bail as a means of assuring the accused's presence at trial. ${ }^{154}$ Thus, the unavailability of bail in the military establishment may be less significant than might first appear. Furthermore, military justice insists on a speedy trial so that pretrial confinement may prove much shorter for a military accused than for his civilian counterpart who fails to make bail. ${ }^{155}$ Even so, military commanders have a degree of discretion as to pretrial confinement unrivaled in civilian life.

\section{Statements and Reports}

Often military authorities will be in an advantageous position to obtain admissions from a suspect. For one thing, the suspect will frequently be young, in-

\footnotetext{
${ }^{188}$ U.C.M.J., art. Io, to U.S.C. $\$ 810$ (1970).

${ }^{140}$ Manual, I 20c. The Task Force has recommended that

[p]rocedures concerning the admission of an accused into pretrial confinement and retention therein in each service be standardized with a view towards limiting the opportunity for the abuse of discretion and enhancing the perception of fairness, such procedures to include the appointment of both a qualified judge advocate defense counsel to talk with each accused prior to his entry into pretrial confinement or shortly thereafter, and a legal officer, independent of the confining command, authorized to review the pretrial confinement and release the accused from confinement as the circumstances warrant; the confinee be served with a copy of any letter requesting or granting permission for pretrial confinement in excess of thirty days; persons placed in pretrial confinement for less serious offenses be segregated from those placed in pretrial confinement for more serious offenses; and the accused, if found guilty, be credited for time spent in pretrial confinement.
}

TASK FoRCE REPORT 122.

${ }^{100}$ Cf. Stack v. Boyle, 342 U.S. I (I95I), where assuring the defendent's presence seems to be the sole permissible purpose of bail.

101 Id.

${ }^{162}$ See Levy v. Resor, I7 U.S.C.M.A. 135, 37 C.M.R. 399 (1967).

${ }^{103}$ See 1962 Hearings $847,873,909,925,944,961$. Pretrial confinement contrary to local regulations is illegal. United States v. Gray, 6 U.S.C.M.A. 6I5, 20 C.M.R. 33 I (1956). The Army has authorized certain "military magistrates" to release persons in pretrial confinement. See I97I ANNuaL REPORT, supra note 3, at 321.

164 See, e.g., D. Freed \& P. Ward, Barl in THE UNITED States (I964); Rankin, The Effect of Pretrial Detention, 39 N.Y.U.L. REv. 64I ( 1964$)$; Foote, The Coming Constitutional Crisis in Bail, II3 U. PA. L. REv. 960, II25 (1965). Criticism of bail as the determinant of pretrial confinement gave rise to the Bail Reform Act of 1966,80 Stat. 214, codified in 18 U.S.C. \$\$ 3146-50 (1970).

${ }^{165}$ See, e.g., U.C.M.J., arts. Io, 33, 98, Io U.S.C. \$\$ 810, 833, 898 (1970); MaNuar, II 68i, 215e; United States v. Williams, I6 U.S.C.M.A. 589, 37 C.M.R. 209 (1967). 
experienced, and far away from family and friends; and so he may feel especially isolated and powerless. He may be more subject to pretrial confinement than a suspect would in civilian life. He has been conditioned during his military service to obey an order from his superiors, and a request for a statement regarding an offense may be interpreted by the military suspect as an order to talk. The total effect of these factors may be a strong pressure on a suspect to make admissions. Probably to counteract this pressure, Congress has enacted in Article $3^{\mathrm{I}}$ of the Code a specific requirement that any suspect requested to make a statement must be informed both of the nature of the offense, and that any statement he does make may be used in evidence against him. ${ }^{156}$ This requirement, which preceded the warning requirement of Miranda and which was relied on in that case in Chief Justice Warren's opinion, ${ }^{157}$ does not depend on custodial interrogation. Thus, in one way the discretion of military authorities in obtaining statements is limited by this broad statutory requirement.

Grants of immunity are often a valuable tool for investigators in obtaining statements. Although the Uniform Code does not deal with this subject, the Manual for Courts-Martial provides that "an authority competent to order a person's trial by general court-martial may grant or promise him immunity from trial." ${ }^{\text {"16B }}$ Thus, grants of immunity are within the discretion of military commanders without judicial review.

Various types of reporting requirements are found in civilian life-such as reports of accidents and reports of certain business transactions. ${ }^{160}$ In some manner the duty to report usually derives from a statute. The military commander may also impose requirements on his personnel to report certain events or transactions, but in this instance the requirement stems from military regulation, rather than from statute. ${ }^{100}$

\section{Article 32 Investigation and Staff Judge Advocate's Advice}

For charges that may be referred to a general court-martial, Article 32 of the Uniform Code requires that a thorough and impartial investigation be made. ${ }^{101}$ Provision is made for appointment of an investigator who must inquire into the form and truth of the charges and make a recommendation "as to the disposition

\footnotetext{
í6 U.C.M.J., art. $3 \mathrm{I}$, Io U.S.C. \$83I (1970).

${ }_{167}$ See Miranda v. Arizona, 384 U.S. 436, 498 (1966).

${ }^{158}$ Manuat, q 68h; United States. v. Kirsch, I5 U.S.C.M.A. 84, 35 C.M.R. 56 (1964). Apparently "the immunity authorized is a transactional immunity and not merely the immunity from use of testimony provided under r8 U.S.C. $\$ 6002$ (1970). See also Kastigar v. United States, 408 U.S. 931 (1972). The convening authority and his staff judge advocate are disqualified from reviewing and taking action as to a record of trial in which a government witness has testified under an immunity grant. See United States v. Diaz, 22 U.S.C.M.A. 52, 46 C.M.R. 52 (1972).

${ }^{169}$ See California v. Byers, 402 U.S. 425 (r971); Grosso v. United States, 390 U.S. 62 (I968); Marchetti v. United States, 390 U.S. 39 (1968); Shapiro v. United States, 335 U.S. I (1948), with respect to constitutional limitations on reporting requirements.

${ }^{100}$ Prosecutions for failure to comply with the reporting requirements of military regulations were Involved in United Stataes v. Kauffman, I4 U.S.C.M.A. 283, 34 C.M.R. 63 (1963); United States v. Smith, 9 U.S.C.M.A. 240, 26 C.M.R. 20 (1958). See also Kaufman v. Secretary of the Air Force, 4 I5 F.2d 99x (D.C. Cir. Ig69).

101 U.C.M.J., art. 32, 10 U.S.C. $\$ 832$ (1970).
} 
which should be made of the case in the interest of justice and discipline."162 Thus, the discretion of a military commander is limited by the requirement of this Article 32 investigation, which has sometimes been compared to an inquiry by a civilian grand jury. However, while the return of an indictment is a prerequisite to further proceedings in the federal courts and in those state courts which employ a grand jury, trial by court-martial in the military system can be ordered in the discretion of a military commander regardless of a contrary recommendation by the officer who conducted the pretrial investigation. ${ }^{163}$

As a prerequisite to trial by general court-martial, the convening authority-the commander who convenes the court-martial-must obtain advice from his staff judge advocate or legal officer. ${ }^{164}$ This legal advice must state whether there has been adequate pretrial investigation, whether each charge alleges an offense, and whether the allegations are supported by the evidence in the pretrial investigation. ${ }^{165}$ However, the discretion of the convening authority is not limited by the staff judge advocate's advice; he may still refer for trial any charge that he finds alleges a violation of the Uniform Code and is warranted by evidence indicated in the Article $3^{2}$ pretrial investigation. ${ }^{168}$

\section{E. Referring Charges for Trial}

Charges under the Uniform Code may be signed by any member of the armed forces who swears that he has investigated or has personal knowledge of the matters alleged and that they are true to the best of his knowledge and belief. ${ }^{167}$ However, preferring charges is not especially significant in itself, since military commanders are not required to refer them to a court-martial for trial. ${ }^{168} \mathrm{~A}$ military commander

${ }^{103}$ The statute speaks only of a "recommendation" by the investigating officer. See U.C.M.J., art. $32(a)$, to U.S.C. $\$ 832$ (a) (1970). See also Manual, 134 . If a charge is referred to a general courtmartial for trial, the convening authority must find "that the charge alleges an offense under this chapter and is warranted by evidence indicated in the report of investigation." U.C.M.J., art. 34(b), Io U.S.C. $\$ 834$ (b) (I970).

${ }^{104}$ U.C.M.J., art. $34(\mathrm{a})$, ro U.S.C. $\$ 834$ (a) (1970).

${ }^{100}$ Mandal, 135c. The staff judge advocate also provides "a signed recommendation of the action to be taken by the convening authority" and this "recommendation will accompany the charges if they are referred for trial." Id.

100 U.C.M.J., art. 34 , Io U.S.C. $\$ 834$ (1970).

${ }^{107}$ U.C.M.J., art. 30 , Io U.S.C. $\$ 830$ (I970). However, a" "person subject to the code cannot be ordered to prefer charges to which he is unable truthfully to make the required oath on his own responsibility." ManUaL, I $29 c$.

${ }^{108}$ The statutory obligation is that "[u]pon the preferring of charges, the proper authority shall take immediate steps to determine what disposition should be made thereof in the interest of justice and discipline, and the person accused shall be informed of the charges against him as soon as practicable." U.C.M.J., art. 30, Io U.S.C. $\$ 830$ (1970). The Manual requires a "preliminary inquiry into the charges"; but this inquiry can be informal. MaNual, \32b. On the basis of this preliminary inquiry, the accused's immediate military commander may determine to dismiss the charges that have been preferred, unless he is directed to the contrary by competent superior authority. Id., I $32 d$. If the commander dismisses all the charges, he may-but apparently is not required to-"notify the accuser of the action taken and the reasons therefor." $I d$. ., I $32 d$. Even for serious charges, there is no requirement that a formal investigation be conducted under Article 32 as a prerequisite for dismissal.

The convening authority's discretion to determine whether to refer charges for trial and, if so, to what grade of court-martial is a personal discretion and cannot be delegated. United States v. Simpson,
} 
has full discretion to refuse to prosecute, subject to being overruled by a military superior and ordered to take action on the charges. There is, however, no military grand jury that can indict against his wishes. ${ }^{169}$ Nor is it likely that a military commander could be himself prosecuted successfully for dereliction of duties by reason of his failure to refer charges for trial. ${ }^{170}$

There are three types of court-martial: (a) the general court-martial, which may impose any punishment authorized by the Code and the Manual for CourtsMartial; $;^{171}$ (b) the special court-martial, which may adjudge no punishment greater than a bad conduct discharge, confinement for up to six months, and forfeiture of up to two-thirds pay for up to six months; ; $^{172}$ and (c) the summary court-martial, which may not adjudge punishment greater than confinement for one month and forfeiture of two-thirds pay for one month. ${ }^{173}$ Basically the authority to convene a particular type of court-martial and refer cases to it for trial depends on the position of a commander in the military hierarchy of command. Thus, a general courtmartial may be convened by the President, the secretary of the military department concerned, or the commander of a division, a fleet, a naval station, an Air Force or Marine Corps wing. ${ }^{174}$ A special court-martial may be convened by any person who may convene a general court-martial and various commanders at lower echelons, such as the commanders of an Air Force base or an Army or Marine Corps brigade or regiment and the captain of a naval or Coast Guard vessel. ${ }^{175}$ A summary courtmartial may be convened by any person who may convene a general or special courtmartial, the commanding officer of a detached company or other detachment of the Army, and the commanding officer of a detached squadron or other detachment of the Air Force. ${ }^{176}$ With respect to all three types of courts-martial, Congress granted the secretary of a military department the power to designate other commanding .officers who might act as convening authorities; ${ }^{177}$ and the same power was given the President as to general courts-martial. ${ }^{178}$

I6 U.S.C.M.A. I37, 36 C.M.R. 293 (r966); United States v. Robert, 7 U.S.C.M.A. 322, 22 C.M.R. Ir2 (1956); United States v. Bunting, 4 U.S.C.M.A. 83 , I5 C.M.R. 84 (1954).

${ }_{100}$ United States v. Cox, 342 F.2d 167 (5th Cir. 1965), seems to hold that a federal grand jury cannot return a valid indictment without the cooperation of the United States attorney, who must sign an indictment before it may become a basis for prosecution.

${ }^{170}$ A military commander has certain duties with respect to the maintenance of discipline among his troops. See In re Yamashita, 327 U.S. I (1946). Thus, if a commander repeatedly dismissed charges that had been preferred against members of his command and that clearly had merit, he might be subject to prosecution under U.C.M.J., Article 92, Io U.S.C. $\$ 892$ (1970), for dereliction of dutics as a commander. However, a factual situation that would permit successful prosecution on this basis is unlikely. The repeated dismissal of charges would probably not constitute a violation of Article 98 , which proscribes noncompliance with procedural rules. U.C.M.J., art. 98, 10 U.S.C. $\$ 898$ (1970).

${ }^{171}$ U.C.M.J., art. I8, Io U.S.C. $\$ 8$ I8 (I970).

${ }^{172}$ U.C.M.J., art, 19 , 10 U.S.C. \$ $8 \mathrm{rg}$ (1970).

${ }^{173}$ U.C.M.J., art 20, 10 U.S.C. \$ 820 (1970).

${ }^{174}$ U.C.M.J., art. 22, 10 U.S.C. $\$ 822$ (I970).

${ }^{175}$ U.C.M.J., art. 23, 10 U.S.C. $\$ 823$ (1970).

${ }^{170}$ U.C.M.J., art. 24 , Io U.S.C. \$ 824 (1970).

${ }^{172}$ U.C.M.J., arts. $22(a)(6), 23(a)(7), 24(a)(4)$, ro U.S.C. $\$ \$ 822(a)(6), 823(a)(7), 824(a)(4)$ (1970).

${ }^{178}$ U.C.M.J., art $22(\mathrm{a})(7)$, 10 U.S.C. $\$ 822(\mathrm{a})(7)$ (1970). 
If a commander is not authorized to convene a court-martial which would have jurisdiction to adjudge the punishment which, in his opinion, is suitable for the offense charged, he may transmit the charges to a commander of higher rank for determination of the action to be taken. For example, a company commander in the Army would usually not have authority to convene any type of court-martial; his only method for imposing punishment would be by means of nonjudicial punishment under Article I5 of the Uniform Code. Therefore, if the company commander did not feel that the case was suitable for disposition under Article ${ }_{5}$ but that further action should be taken, he could transmit the charges to the Army regimental or brigade commander, who would have power to convene either a summary or special court-martial. If that commander felt that the charges might warrant trial by general court-martial, he could take steps to transmit the case to the division commander or some other higher commander with authority to convene a general court-martial. In the Air Force, the progression might be from the squadron commander to a group or base commander, and then to the commander of a separate wing or of some other higher command. In the Navy, fewer steps would be involved, for the captain of a vessel would have the authority either to mete out nonjudicial punishment or to convene a summary or a special court-martial.

The broad discretion conferred upon military commanders with respect to referring charges for trial by court-martial is limited in two important ways. Neither a general nor a special court-martial may be convened by a commanding officer who is an "accuser"179 - a term which has been broadly defined by the Code ${ }^{180}$ and by the Court of Military Appeals. For example, a general whose home had been burglarized could not convene a court-martial to try the accused; ${ }^{181}$ and in one case it was held that a general who attempted to convene a court-martial for disobedience of an order issued in his name was disqualified by his personal interest in the result. ${ }^{182}$

Even an accuser can convene a summary court-martial. Thus, the second limitation on the commander's discretion is especially important. Article 20 provides an absolute right to object to trial by summary court-martial. ${ }^{183}$ However, this right itself contains some peril since the accused who objects to trial by summary courtmartial, which is limited in jurisdiction to the imposition of no more than one month's confinement, may thereby risk trial by general or special court-martial, which may adjudge a more serious punishment. ${ }^{184}$

\footnotetext{
${ }^{170}$ U.C.M.J., arts. 22 (b), 23 (b), I0 U.S.C. $\$ \$ 822$ (b), 823 (b) (I970).

${ }^{280}$ Article $I(9)$ of the U.C.M.J., Io U.S.C. $\$ 80 I(9)$ (I970), defines accuser as "a person who signs and swears to charges, any person who directs that charges nominally be signed and sworn to by another, and any other person who has an interest other than an official interest in the prosecution of the accused."

${ }^{181}$ United States v. Gordon, I U.S.C.M.A. 255, 2 C.M.R. I6I (I952).

${ }^{182}$ United States v. Marsh, 3 U.S.C.M.A. 48, rI C.M.R. 48 (1953); but of. United States v. Teel, 4 U.S.C.M.A. 39, I5 C.M.R. 39 (I954); United States v. Keith, 3 U.S.C.M.A. 579, 13 C.M.R. I35 (I953).

${ }^{183}$ Prior to the effective date of the Military Justice Act of 1968 an accused could object to trial by summary court-martial only if he had not been offered nonjudicial punishment pursuant to Article I5. 184 At one time it seemed arguable that the determination of military authorities to refer the charges
} 


\section{Appointment of Court-Martial Personnel}

Considerable invective has been directed against military justice because of the opportunities for a military commander as convening authority of a court-martial to influence the outcome of a case tried by that court. While these opportunities were significantly curtailed by the Military Justice Act of I968, they have not completely been eliminated.

\section{A. General Courts-Martial}

Prior to the effective date of the I 968 legislation, only one type of general courtmartial existed, and it was composed of a "law officer" and not less than five members. ${ }^{185}$ In the Army and later in the Navy and Marine Corps, the law officers were members of a trial judiciary which performed only duties in connection with general courts-martial and which was considerably insulated from the influence of military commanders. ${ }^{180}$ In the Air Force full-time law officers were not utilized and the military lawyers who acted as law officers were much less protected from the possibility of command influence. The Military Justice Act of Ig68 redesignated the law officers as military judges, ${ }^{187}$ provided a statutory basis for the trial judiciary, and attempted to safeguard their independence. ${ }^{188}$ Furthermore, a general courtmartial might consist of "only a military judge, if before the court is assembled the accused, knowing the identity of the military judge and after consultation with defense counsel, requests in writing a court composed only of a military judge and the military judge approves." 180 Here then is authorized waiver of jury-and without the consent of the Government, which is required in the federal courts. ${ }^{190}$ Such a waiver is especially significant since in the traditional general court-martial with lay members, the "military jury" not only returns the verdict but also imposes the sentence.

to a summary court-martial for trial would have the practical effect of limiting the punishment imposable to that which could be adjudged by a summary court-martial, even if the accused objected to trial by summary court-martial and the charges were then referred to a special or general court-martial. Otherwise the possibility of greater punishment would have a "chilling effect" on the accused's statutory right to object to trial by court-martial. Cf. United States v. Jackson, 390 U.S. 570 (xg68). A similar argument can be made with respect to the punishment imposable if an accused objects to nonjudicial punishment and charges are referred for trial by court-martial. However, the Supreme Court has now made this position seem almost untenable. Cf. Colten v. Kentucky, 407 U.S. I04 (1972).

${ }^{185}$ See R. EVERETr, supra note 42 , at $145-57$.

${ }^{180}$ See 1962 Hearings $838-40,904-05,936-37$.

${ }^{187}$ U.C.M.J., arts. $x(10), 26$, xo U.S.C. $\$ 801(x 0), 826$ (1970). The redesignation of the "law" officer" to "military judge" is paralleled by the recent change of title from "hearing examiner" to "administrative law judge." 4 I U.S.L.W. 2 II5.

.288.U.C.M.J., arts. $26(\mathrm{c}), 37$, 10 U.S.C. $\$ \$ 826(\mathrm{c}), 837$ (1970). The officer certified for duty as military judge of general courts-martial is "directly responsible to the Judge Advocate General, or his designee."

${ }^{189}$ U.C.M.J., art. $16(\mathrm{r})(\mathrm{B})$, ro U.S.C. $\$ 816(\mathrm{r})(\mathrm{B})$ (1970).

${ }^{200}$ FED. R. Crms. P. 23 (a); Singer v. United States, 380 U.S. 24 (rg65). 


\section{B. Special Courts-Martial}

Before the Military Justice Act of Ig68 special courts-martial could only consist of not less than three members. Now alternative arrangements are possible. The courtmartial may consist of a military judge and not less than three members. Or, it may be staffed by a military judge if one has been detailed to the court and the accused, knowing his identity and after consultation with defense counsel, so requests in writing, and the military judge approves. ${ }^{191}$ In the instance of the special courtmartial the military judge may be, but is not required to be, a member of the trial judiciary whose duties are solely of a judicial nature. Moreover, he is subject to the influence of military commanders in the field through their power over his assignments and through their control of his performance ratings. ${ }^{192}$ Thus, for special courts-martial there remains the possibility that a military commander-if he is willing to achieve his end despite an express statutory prohibition in the Uniform $\mathrm{Code}^{103}$-may influence the military judge's performance of duties. Also, for the special court-martial the military commander in the field may have some ability to control what military judge will be assigned to a particular case.

The commander who serves as convening authority may also determine if the special court-martial will have a military judge, since there is no statutory requirement that a special court-martial have a military judge. His discretion is, however, severely limited in practice. For one thing, a special court-martial without a military judge cannot impose a bad conduct discharge "except in any case in which a military judge could not be detailed to the trial because of physical conditions or military exigencies."194 Furthermore, in any such case the convening authority must "make a detailed written statement, to be appended to the record, stating the reason or reasons a military judge could not be detailed." 195 It is perfectly clear that Congress intended for few cases, indeed, to be disposed of under this exception. Since many of the cases referred to special court-martial would be those where the convening authority would wish the court to be free to impose a bad conduct discharge, he will be under considerable compulsion to appoint a military judge to the court-martial.

\footnotetext{
${ }^{101}$ U.C.M.J., art. I6(2)(C), Io U.S.C. $\$ 8 \mathrm{r6}(2)$ (C) (I970).

${ }^{103}$ See U.C.M.J., art. 26 (c), I0 U.S.C. $\$ 826$ (c) (1970). Article 37 (b) provides that, in preparing an effectiveness, fitness, or efficiency report, no one may "consider or evaluate the performance of duty ... as a member of a court-martial." U.C.M.J., art. 37 (b), 10 U.S.C. $\$ 837$ (b) (1970). In this context the word "member" may not include the "military judge" who has been detailed to a special court-martial and who is not certified to serve as military judge of general courts-martial. However, any omission in the statutory wording is remedied by the Manual provision that "a convening authority shall not prepare or review any report concerning the effectiveness, fitness, or efficiency of a military judge detailed to a special court-martial which relates to his performance of duty as a military judge." Manual, $\$ 38 e(2)$. The ratings in these reports are a major factor in determining an officer's assignments, promotion, qualification for a regular commission, and retention in the service.

The Air Force has recently expanded its Trial Judiciary to provide 28 full-time military judges for special courts-martial. These officers will be assigned directly to the Office of the Judge Advocate Gencral and thus will not be subject to efficiency ratings by commanders in the field. AFJAG REPORTER, Aug., 1972, at 21 .

${ }_{100}$ U.C.M.J., art. 37, ro U.S.C. $\$ 837$ (1970).

106 U.C.M.J., art. I9, Io U.S.C. \$ 819 (I970).

${ }^{100}$ Id.
} 
A second practical consideration is created by the increased presence of legallytrained defense counsel in special courts-martial. Prior to the Military Justice Act of Ig68, there was no requirement that a military lawyer be assigned to represent the accused, unless the prosecutor was a lawyer. Although the Air Force generally provided lawyers both to prosecute and defend in special courts-martial, this was not true in the Army and Navy. ${ }^{196}$ The 1968 legislation required that the accused be provided legally-trained counsel in special courts-martial "unless counsel having such qualifications cannot be obtained on account of physical conditions or military exigencies."197 Moreover, the convening authority must make a "detailed written statement, to be appended to the record, stating why counsel with such qualification could not be obtained." ${ }^{198}$ The result has been the appointment of military lawyers as defense counsel in almost all special courts-martial tried since the 1968 Act took effect. ${ }^{199}$ If a lawyer is to defend, then generally the convening authority wishes to have a lawyer as trial counsel-prosecutor--to protect the Government's interests. In turn, experience has demonstrated that trial by a special court-martial composed only of lay members in a case where lawyers are prosecuting and defending is often very unsatisfactory. The members are frequently confused by legal issues as to which they have available no impartial source of advice. Thus, another very strong practical pressure exists for a convening authority to appoint a military judge to a special court-martial.

Before the requirement existed that lawyers be appointed to defend an accused tried by a special court-martial, a convening authority had considerable leeway to influence the quality of the defense, for among the non-legally-trained officers appointed as defense counsel in special courts-martial the aptitude for court-martial practice and the zeal displayed might vary markedly. Even today the convening authority is in a position to affect the quality of defense representation by his decisions concerning which lawyers in his command will be appointed or made available as defense counsel. However, the accused is assured at least a minimal level of skill on the part of his counsel, for the lawyer must be a licensed attorney or the graduate of an accredited law school and must also be certified by the Judge Advocate of his armed force as being competent to defend general courts-martial. ${ }^{200}$ Moreover, the Air Force has undertaken a pilot program for trial teams composed of full-time trial and defense counsel to prosecute and defend general and special courts-martial.

\footnotetext{
${ }^{206}$ 1962 Hearings 837-38, 903, 935. The Court of Military Appeals did not consider legally-trained defense counsel to be constitutionally required in a special court-martial, even when a bad conduct discharge was adjudged. See United States v. Culp, I4 U.S.C.M.A. 199, 33 C.M.R. 4 II (1963).

${ }^{207}$ U.C.M.J., art. $27(\mathrm{c})(\mathrm{x})$, to U.S.C. \$ 827 (c) (I) (x970).

${ }^{208}$ Id.

${ }^{199}$ The Military Justice Act of 1968, 82 Stat. 1355, took effect on Aug. I, 1969. The requirement that legally-trained counsel be provided in connection with special courts-martial created an added need for lawyers in the Army and the Navy.

${ }^{200}$ U.C.M.J., art. 27 , 10 U.S.C. $\$ 827$ (1970).
} 
In addition to their greater experience, the members of the trial team are insulated more fully from command influence on their performance. ${ }^{201}$

\section{Summary Courts-Martial}

In a summary court-martial the convening authority, who is not disqualified by any personal interest, appoints a commissioned officer who serves as the summary court-martial. While neither the Code nor the Manual contemplate the appointment of counsel for such a court-martial, the recent ruling of the Supreme Court in Argersinger v. Hamlin ${ }^{202}$ requires a reassessment in this regard. However, the military establishment may take the position that the absolute right to object to trial by summary court-martial-in which event the case will only be tried by special or general court-martial where legally-trained counsel are provided-distinguishes the Argersinger case. ${ }^{203}$ 201 On June I, I97x, the pilot project for the Air Force Judiciary Trial Division officially began its
test period. This project, which was discussed in the January I, 1970-December 31 , I970 report,
is one in which some I5 judge advocates were assigned as fulltime trial and defense counsel and
special court-martial military judges within geographical districts within the 2d Circuit of the
eastern U.S. Judiciary Region. They work out of offices at Maxwell AFB, Ala., Keesler AFB, Miss.,
MacDill AFB, Fla., and Shaw AFB, S.C. All report directly to the Judge Advocate General rather
than field commanders. The test period was concluded on November 30, I97I, and is currently
undergoing an evaluation with a view toward determining its feasibility for worldwide adoption.

197I Annul Report, stpra note 3, at 33. A similar approach was suggested in 1962 by Dean A. Kenneth Pye. See 1962 Hearings 548-49. The pilot program has apparently been successful and is being expanded. See AFJAG REPORTER, Aug., I972, at 2I. With respect to counsel, the Task Force has recommended that there be provided:

[a]dequate legal facilities and services to military judges and military counsel, including proper office equipment, adequate legal libraries, private offices for defense counsel and trial counsel, separated so that they will not appear to be working out of the same organization, and necessary logistical and administrative support (e.g., paralegal representation and enlisted investigative assistants).... [t] he senior circuit judge appoint members of court and detail the military judge and defense counsel made available to him. Members of the trial judiciary be placed under the direction of the appropriate Judge Advocate General. All judge advocate defense counsel be placed under the direction of the appropriate Judge Advocate General or, in the case of the Marine Corps, the Director, Judge Advocate Division, Headquarters, United States Marine Corps. In view of the critical need for more minority lawyers, the feasibility of contracting for a pool of minority civilian defense counsel from which the military could draw, as needed, be explored; and adequate funds be made available to the services for the express purpose of expanding their efforts in recruiting minority lawyers. Military counsel be provided with additional training in human relations and in communicating with minority persons.

TASK Force RePORT I24-25.

202407 U.S. 25 (I972).

${ }^{203}$ U.C.M.J., art. 20 , to U.S.C. $\$ 820$ (1970). In four summary court-martial cases the Judge Advocate General of the Army has set aside the confinement portion of the sentence since the accused were neither represented by lawyer counsel at trial nor did the accused knowingly and intelligently waive their right to representation by lawyer counsel. 72-I4 JUDGE Advocate LEGAL SERVICE §III(3) (DA Pam 27-72-I4). For a federal district court holding that Argersinger applies to summary courtsmartial, see Daigle v. Warner, 348 F. Supp. 1074 (D. Hawaii 1972). Under the same reasoning, does Argersinger apply to nonjudicial punishment involving correctional custody?

The Task Force has recommended a decrease in the use of the summary court-martial with a view toward its eventual abolishment. Pending this, the Task Force suggests several modifications to ensure the appearance of fairness in the operation of summary courts-martial. These include: only judge advocates should be appointed to sit as summary court-martial officers; counsel should be detailed to represent the accused and the Government; the nature of the summary court-martial should be an 


\section{Determining the Number of Court Members}

Neither a general court-martial nor a special court-martial need contain a prescribed number of members-only a minimum number. Thus, the convening aut thority can determine the number of members to serve on the court-martial, subject to the right of the accused to reduce this number by use of peremptory challenge or challenge for cause. The number appointed may be significant, since military justice does not require a unanimous verdict and findings of guilty may be returned by a two-thirds vote. ${ }^{204}$ From the standpoint of an accused contesting guilt, a courtmartial composed of five or eight members is preferable to one composed of six or nine members. ${ }^{205}$

\section{E. Pretrial Instruction}

Prior to the Military Justice Act of rg68 a convening authority could instruct or lecture prospective court-martial members, and if the instructions were sufficiently astute, they would not fall within the proscription of unlawful influence on a courtmartial. ${ }^{206}$ Article 37 of the Code now markedly limits this practice. ${ }^{207}$ It also imposes other limitations on actions of the convening authority that might tend to influence court members. However, he still retains the power to appoint the members; and, so the criticism goes, he can manipulate his appointments in a way that will stack the court. Furthermore, the court members are still usually the military subordinates of the commander who appoints them.

\section{F. Enlisted Membership}

In the instance of enlisted accused, the commander's discretion is limited by the right of an enlisted man to request in writing that the membership of his court-

adversary proceeding; the evidence of conviction by summary court-martial should be removed from an accused's field file upon reenlistment or release from active duty; and summary courts-martial should be empowered to impose correctional custody.

Although a minority of the Task Force felt that the summary court-martial still serves a valid purpose and provides a useful array of options for the benefit of the accused, the majority believed that elimination of the summary court would achieve three important results: the ends of justice would be better served; fewer persons would have their records marred by court-martial convictions; and trial by special court-martial would involve adequate procedural protection of the rights of the individual accused. TASK Force Report 76-77.

206 U.C.M.J., art. 52, Io U.S.C. $\$ 852$ (1970). Cf. Apodaca v. Oregon, 406 U.S. 404 (1972) (unanimous verdict is not required as part of the constitutional right to a jury trial); Williams v. Florida, 399 U.S. 78 (r970) (right to jury trial does not require twelve-member jury).

${ }^{206}$ See R. EVERETT, supta note 42 , at I79.

- ${ }^{206}$ See, e.g., United States v. Danzine, I2 U.S.C.M.A. 350, 30 C.M.R. 350 (I96I). Paragraph 38 of the I95r Manual for Courts-Martial authorized the convening authority to give "general instruction to the personnel of a court-martial which he has appointed, preferably before any cases have been referred to the court for trial. : . . Such instruction may relate to the rules of evidence, burden of proof, and presumption of innocence, and may include information as to the state of discipline in the command, as to the prevalence of offenses which have impaired efficiency and discipline, and of command measures which have been taken to prevent offenses." Because of complaints about the practice of giving pretrial instruction to prospective court-martial members, the Army discontinued this practice in 1962 . See 1962 Hearings 869, 923 ("Handbook for Court Members" sponsored by the Navy to obviate the need for special instructions to-court members).

${ }^{207}$ U.C.M.J., art. 37, 10 U.S.C. $\$ 837$ (1970). 
martial be comprised of at least one-third enlisted personnel. ${ }^{208}$ As this right is implemented by the Manual for Courts-Martial, it applies throughout the trial, so that, if by challenges, illness, or otherwise, the enlisted membership of the courtmartial is reduced below one-third, then the trial cannot proceed. ${ }^{209}$ The one-third requirement can be valuable to an enlisted accused whose defense counsel foresees that enlisted members of a court-martial would probably vote to acquit. By peremptorily challenging an officer member of the court-martial, the defense can increase the enlisted membership above one-third and thereby prevent the Government from obtaining the two-thirds vote required for conviction. Such cases, however, do not arise in practice. Instead, many experienced defense counsel have found that when an accused requests enlisted membership, those appointed are typically senior non-commissioned officers with a predisposition toward the prosecution. Military commanders have found authorization for such appointments in the Uniform Code's mandate that a convening authority detail as members persons "who are best qualified for the duty by reason of age, education-training, experience, length of service, and judicial temperament."210 Many military commanders seem to believe that no enlisted man could be better qualified within these guidelines than a top sergeant or a chief petty officer. The Court of Military Appeals permits this view.211 Thus, provisions for enlisted court membership have become almost a dead letter because of defense reluctance to utilize this option.

\section{G. Selection of Court Members}

The Uniform Code directs that "when it can be avoided, no member of an armed force may be tried by a court-martial any member of which is junior to him in rank or grade."212 To some extent this standard may reflect the deference afforded rank by military custom. It may also be grounded on very practical concerns that a subordinate of the accused might be influenced by fear, resentment, or some other improper motive. In any event, it provides no serious limitation on the discretion of a convening authority who wishes to "stack" membership of a court-martial to achieve a particular result.

Various legislative proposals have been made to limit the discretion of military commanders in the appointment of court members. Some would remove completely the power of the military commander to appoint the members of a court-martial to which he refers charges. ${ }^{213}$ Other proposals would require random selection of court members from a predesignated roster, appointment of court members from

\footnotetext{
${ }^{208}$ U.C.M.J., art. 25 (c), to U.S.C. $\$ 825$ (c) (1970).

${ }^{200}$ MANUAL, I $62 h(4)$. (1970).

${ }^{10}$ U.C.M.J., art. 25 (d) (2), Io U.S.C. $\$ 825$ (d) (2) (I970). Cf. Carter v. Jury Comm'r, 396 U.S. 320

${ }^{211}$ United States v. Crawford, I5 U.S.C.M.A. 3x, 35 C.M.R. 3 (1964), discussed in I965 DURE I.J. 633. For criticism of this case and of prevailing practice in the selection of court-martial members, see Remcho, Military Juries: Constitutional Analysis and the Need for Reform, 47 IND. L.J. I93 (1972). See also United States v. Greene, 20 U.S.C.M.A. 232, 43 C.M.R. 72 (1970).

212 U.C.M.J., art. 25 (d) (I), Io U.S.C. $\$ 825$ (d) (I) (I970).

21s Bayh, supra note 3 , at I9; Sherman, supra note 3 , at 45 .
} 
the lower enlisted grades for the trial of enlisted personnel, or appointment of court members from different military commands. ${ }^{214}$ Although such proposals would eliminate some of the opportunities for abuse that have been complained of, none would completely remove every possibility of abuse, since the court members would still be military personnel who might feel subject to the possibility of military reprisal by a disgruntled commander.

While several of these proposals would require enabling legislation, some of them could be implemented administratively. For example, by agreement between military commanders, court-martial members could be appointed who were not under the command of the convening authority. Of course, even in that instance the possibility of reprisal pursuant to agreement between the commanders involved would still exist; and, in practice, commanders would probably be reluctant to spare members of their own organization to help solve the disciplinary problems of another organization. Similarly, random selection could be utilized by a commander. With the aid of his personnel officers he could appoint members of his command who were selected on a random basis from the officers in his command. ${ }^{215}$ Conceivably, however, under the existing provisions of the Code, random selection might be regarded as inconsistent with the exercise of the commander's discretion in choosing the "best qualified," as contemplated by the statutory wording. ${ }^{210}$

\section{$\mathrm{V}$ \\ Trial}

As has already been explained, the convening authority determines if charges will be referred for trial by court-martial, and his determination may be at odds with the recommendations of an Article 32 investigating officer or of the convening authority's own staff judge advocate. Furthermore, it appears from the Manual for Courts-Martial that a trial counsel has no independent power to refuse to prosecute a case which the convening authority wishes tried. According to the Manual, a trial counsel who, while preparing a case for trial, discovers that trial would be inadvisable is directed to "inform the convening authority at once."217

\footnotetext{
214 Id. See also Remcho, supra note 21I, at 223-29.

${ }^{215}$ In one case random selection was apparently used by a convening authority in appointing courtmartial members. See Remcho, supra note 211, at 219. The Task Force has recommended selection of court members on a random basis and that "[a]dditional peremptory challenges to the court members be permitted by both prosecution and defense, with the defense having a greater number than the prosecution." TASK FORCE REPORT 225.

${ }^{210}$ The language of Article 25 seems to contemplate that the commander who convenes a courtmartial will use his personal discretion in choosing court members. U.C.M.J., art. 25(d)(2), ro U.S.C. $\S 823$ (d)(2) (1970). In one sense random selection is the antithesis of conscious selection by a commander of the persons whom he deems best qualified to perform duties as court members pursuant to the standards prescribed in Article 25 (d)(2). On the other hand, there is a rational exercise of discretion in a commander's choice to utilize the principle of random selection. United States v. Kemp, No. 25,893 (U.S.C.M.A., filed Nov. 20, 1972), now pending in the Court of Military Appeals, raises the question of the extent to which the convening authority must be personally involved in the various aspects of selecting court members.

${ }^{217}$ Manuar, I $44 f(5)$.
} 
Obviously the convening authority is to make the final determination whether trial will proceed.

Unlike civil courts where venue is an important concept, military justice does not designate the place where a trial by court-martial may be conducted. Thus, a convening authority has some discretion as to the place at which an accused may be brought to trial. Change of venue is authorized but only when "there exists at the place of trial so great a general atmosphere of prejudice against him that he cannot obtain a fair and impartial trial in that place."218

A convening authority may direct that an offense that otherwise would be capital shall be tried as noncapital. ${ }^{219}$ By so doing, he may affect the rules of evidence applicable to the case, especiaily with respect to depositions, which are not admissible in behalf of the prosecution in capital cases. ${ }^{20}$ Also, the convening authority may be involved in a decision concerning the right of the defense to subpoena a civilian witness $^{221}$-although the matter may be reopened at trial. He may forbid the taking of depositions before trial. ${ }^{22}$ At the trial, if a charge has been' held to be defective and inadequate to allege an offense, the matter is referred to the convening authority for action. 223

Plea bargaining is a prevalent feature of civilian criminal justice. Similarly it is employed within the military establishment, although not in all the armed forces. For a decade the Army, Navy, and Marine Corps have utilized plea bargaining; the Air Force, on the other hand, forbids it. ${ }^{224}$ In the military procedure for plea bargaining, the convening authority who has referred a case for trial plays a major role. Upon the initiative of the defense counsel, a written agreement is entered between the accused and the convening authority that, if the accused pleads guilty, the convening authority will approve no sentence in excess of that which is agreed upon. The agreement sets only a ceiling, but not a floor. The defense counsel is still under a duty to seek the lowest possible sentence from the court-martial, the nembers of which are unaware of the agreement between the accused and the convening authority. If the sentence imposed proves to be greater than that which has been agreed upon, then the convening authority reduces the sentence as required. On the other hand, if the sentence adjudged is below that which has been

\footnotetext{
218 MaNUaI, q6ge.

210 Mandar, f $15 a(3)$.

${ }^{220}$ U.C.M.J., art. 49, 1o U.S.C. $\$ 849$ (a) (1970); MANUAL, I I $45 a$.

${ }^{221}$ Manual, I I45a. The convening authority may also be involved in determining whether certain confidential and secret evidence is made available to defense counsel. Manuar, I I5Ib(3).

${ }^{223}$ See U.C.M.J., art. 49 (a), 10 U.S.C. $\$ 849$ (a) (1970).

${ }^{223}$ Manual, Q9 $67 f ; 69 b$; U.C.M.J., art. 62(a), Io U.S.C. $\$ 862$ (a) (1970); Priest v. Koch, 19 U.S.C.M.A. 293, 4 I C.M.R. 293 (1970). Under Article 62, the convening authority may review a military judge's ruling favorable to the accused on a motion to dismiss; however, he cannot make find-. ings of fact contrary to those of the judge. U.C.M.J., art. 62 , ro U.S.C. $\$ 862$ (1970). See United States v. Frazier, 21 U.S.C.M.A. 444, 45 C.M.R. $2 \times 8$ (1972).

${ }_{221}$ For a discussion of the plea bargaining practices in the various armed services, see 1962 Hearings $843,870,905,923,937,957$. See also the judges' view on the negotiated guilty plea program as expressed in United States v. Watkins, II U.S.C.M.A. 6II, 29 C.M.R. 427 (1960). See McMenamin, Plea Bargaining in the Military, Io AM. CaIM. L. REV. 93 (I97x).
} 
agreed upon, there is no procedure for increasing it and the accused receives a windfall of sorts. This procedure, which conforms to all constitutional requirements, ${ }^{225}$ gives the convening authority a discretion and responsibility that many judges do not possess. However, unlike plea bargaining in some civil courts, the bargained plea in the military is embodied in a document before trial. ${ }^{226}$

\section{VI}

\section{Apperrate ReView}

The military commander who convenes a court-martial has considerable discretion in the review of its decision. While he is expected to rely upon the advice of his staff judge advocate, ${ }^{227}$ he retains final responsibility. It is in his power to review the facts, law, and sentence, but his discretion can be exercised only in behalf of the accused.228 The discretion to grant clemency is an absolute one, and can be predicated upon information, such as lie detector results, which would be inadmissible in a trial. ${ }^{229}$ The convening authority can determine whether to suspend all or part of a sentence; ${ }^{230}$ he may defer confinement under certain circumstances; ${ }^{231}$ and he designates the place of confinement, subject to applicable regulations of his military department. ${ }^{232}$ Thus, the initial determination as to rehabilitation is that of the convening authority.

It has been suggested that the broad discretion of the commander is so great that it may sometimes produce an adverse effect on the accused at the trial. Court members may conclude that they should impose a severe sentence and rely on the discretion of the convening authority to reduce it to a suitable level. Obviously such reasoning by court members would violate their sworn responsibility. ${ }^{233}$

Perhaps in response to the possibilities of abuse at the trial level, Congress has provided for extensive appellate review of courts-martial. For example, in addition to initial review by the convening authority, a Court of Military Review must review any case in which there is a punitive discharge or confinement for a year or

\footnotetext{
${ }^{225}$ In United States v. Care, I8 U.S.C.M.A. 535, 40 C.M.R. 247 (1969), the Court of Military Appeals acted to assure that military pleas of guilty would conform to the requirements of Boykin v. Alabama, 395 U.S. 238 (I969), and McCarthy v. United States, 394 U.S. 459 (I969).

${ }^{220} \mathrm{Sec}$ MeMenamin, supra note 224 , at 95 , who favors the visibility of the written pretrial agreement. The military procedure tends to avoid problems like those present in Santobello v. New York, 402 U.S. 994 (I97工).

${ }_{227}$ See Manual, $185 c$. However, if he disagrees with his staff judge advocate, the convening authority should state the reasons for that disagreement. See also id., I gra. The Task Force has recommended that "[i]n other than capital cases, automatic review of all general courts-martial and special courts-martial in which a bad conduct discharge is approved by the convening authority be eliminated, except for a clemency review by the convening authority, providing instead for review by the appellate judiciary of only those cases appealed by the accused." TASK FORCE REPORT 125-26.

${ }^{228}$ Cf. U.C.M.J., arts. 62-64, ro U.S.C. $\$ \$ 862-64$ (r970).

${ }^{220}$ United States v. Massey, 5 U.S.C.M.A. 514, I8 C.M.R. 138 (1955).

${ }^{280}$ U.C.M.J., art. $7 \mathrm{r}(\mathrm{d})$, ro U.S.C. $\$ 8 \mathrm{gr}$ (d) (1970).

${ }^{281}$ U.C.M.J., art. 57 (d), 10 U.S.C. $\$ 857$ (d) (1970).

${ }^{282}$ MANUAL, ๆ $89 C(5)$.

${ }^{288}$ Cf. United States v. Ellis, I5 U.S.C.M.A. 8, 34 C.M.R. 454 (I964).
} 
more. ${ }^{234}$ In other cases, the Judge Advocate General of the appropriate service may act to correct error prejudicial to the substantial rights of the accused. ${ }^{235}$ A petition for new trial is available. ${ }^{236}$ And further relief may be secured through certain administrative boards. ${ }^{237}$

The Court of Military Appeals may review cases which have been reviewed by a Court of Military Review. For the most part the grant of review is discretionary and is upon an accused's petition for review. ${ }^{238}$ Like a Supreme Court denial of certiorari, the denial of a petition for review by the Court of Military Appeals is without a formal opinion. Thus, the criteria for the exercise of its discretion to review can only be surmised. ${ }^{239}$

\section{Concluding Comments}

Traditionally American military commanders, from the Commander-in-Chief down to the company commander, have enjoyed considerable discretion in disciplining their troops. Not surprisingly, the scope of the discretion committed to a a commander frequently depends on his rank, his position in the chain of command, and sometimes on his service. Thus, some of the nonjudicial punishments permissible under Article I5 $_{5}$ depend on the rank of the commander who administers the punishment. ${ }^{240}$ An Army company commander or Air Force squadron commander generally has no authority to convene any sort of court-martial; he can simply transmit charges, with his recommendations, to a higher echelon of command. The captain of a naval or Coast Guard vessel can convene a summary or special court-martial, and as to personnel "attached to or embarked in" his vessel, he may even impose confinement on bread and water, without any election on the part of the accused to elect trial by court-martial. ${ }^{241}$

To some extent the rank of a commander may affect the quality of the justice he administers. Usually there will be some correlation between rank on the one hand, and experience and training on the other. Hopefully, therefore, a seasoned colonel will be able to administer justice more impartially and beneficially than a new lieutenant. However, the converse may be true, and the years of experience may simply reinforce existing prejudices.

The rank of the accused may also affect the scope of the discretion available

\footnotetext{
236 U.C.M.J., art. 66, 10 U.S.C. $\$ 866$ (I970).

${ }^{235}$ U.C.M.J., art. 69 , Io U.S.C. $\$ 869$ (I970). See also Everett, Collateral Attack on Court-Martial Convictions, II A.F. JAG L. REV. 399 (I969).

${ }^{300}$ U.C.M.J., art. 73, 10 U.S.C. $\$ 873$ (1970).

${ }^{237}$ Io U.S.C. $\$ 553$ (I970) (Discharge Review Boards) and Io U.S.C. $\$ 1552$ (I970) (Correction Boards).

${ }^{238}$ U.C.M.J., art. 67 (b), ro U.S.C. $\$ 867$ (b) (1970). However, mandatory review is provided for capital cases and those involving general or flag officers. Also, the Judge Advocate General of an armed service can certify to the court for decision questions arising in cases decided by the Court of Military Review.

${ }^{230}$ The court's most recent annual report reveals that as of June 30 , I97I, it had granted 2,845 petitions for review and had denied 20,793. I97x Annual Report, supra note 3, at 15.

${ }^{210}$ U.C.M.J., art. I5(b), I0 U.S.C. $\$ 815$ (b) (1970).

241 U.C.M.J., art. 15(a), 1o U.S.C. \$815(a) (1970).
} 
to his commander in administering justice. For example, officers may be prosecuted for certain conduct that would not be an offense on the part of an enlisted man. ${ }^{242}$ With respect to nonjudicial punishments, the limitations applicable to officers and enlisted personnel are quite distinct; and as to enlisted personnel the grade of the accused is important in determining the reduction in grade that may be imposed. ${ }^{243}$ No commander-whatever his rank or position-has the power to refer charges against an officer to a summary court-martial for trial. ${ }^{24}$ No officer may be sentenced to hard labor without confinement. ${ }^{245}$ An officer dismissed by order of the President has a right to a trial by general court-martial, ${ }^{240}$ and a sentence extending to dimissal of an officer must be approved by the secretary of the military department. ${ }^{247}$ Cases involving general and flag officers bring into play additional requirements of review. ${ }^{248}$

Congress has sought to limit the discretion of commanders in administering military justice by providing some unique safeguards for service personnel. The detailed appellate review of findings and sentence-which extends to the weight of the evidence and the appropriateness of the sentence, ${ }^{249}$ the Article $3^{I}$ warning required in pretrial interrogation, ${ }^{250}$ and the Article 32 pretrial investigation which must precede trial by general court-martial, ${ }^{251}$ are among these safeguards. Another protection is afforded by the privilege granted any member of the armed forces to make a complaint of wrongs against his commanding officer. ${ }^{252}$

In shielding service personnel against abuses of discretion, military justice has placed great reliance on the numerous elections and options offered to an accused. Unless attached to or embarked in a vessel, he may refuse nonjudicial punishment. ${ }^{253}$ He possesses an absolute right to object to trial by summary court-martial. ${ }^{254}$ In a

\footnotetext{
${ }^{212}$ See, e.g., Articles 88 (contempt toward officials) and 133 (conduct unbecoming an officer and gentleman), U.C.M.J., ro U.S.C. $\$ \$ 888,933$ (1970).

${ }^{243}$ U.C.M.J., art. I5(b) (2)(H) (iv), Io U.S.C. $\$ 815$ (b)(2)(H)(iv) (1970).

2\$ U.C.M.J., art. 20, 10 U.S.C. $\$ 820$ (I970).

205 MaNuaI, \I26d. The 195I Manual for Courts-Martial had provided that an officer could not be sentenced to confinement or total forfeitures of pay unless he was also sentenced to dismissal; but this provision was held to be contrary to the Uniform Code. See United States v. Madison, I4 U.S.C.M.A. 655, 34 C.M.R. 435 (I964); United States v. Smith, ro U.S.C.M.A. I52, 27 C.M.R. 227 (I959).

248 U.C.M.J., art. 4, Io U.S.C. $\$ 804$ (1970).

247 U.C.M.J., art. $7 \mathrm{I}(\mathrm{b})$; Io U.S.C. $\$ 87 \mathrm{I}(\mathrm{b})$ (1970).

218 U.C.M.J., art. 67 (b) (r), Io U.S.C. $\$ 867$ (b) (r) (1970) (mandatory review by Court of Military Appeals); U.C.M.J., art. 7I(a), Io U.S.C. $\$ 87$ I(a) (I970) (approval by the President). The mandatory review for general and flag officers was held to be based upon a reasonable classification. See United States v. Gallagher, I5 U.S.C.M.A. 39I, 35 C.M.R. 363 (I965).

${ }^{240}$ U.C.M.J., arts. $64,66,69$, Io U.S.C. $\$ \$ 864,866,869$ (I970).

280 U.C.M.J., art. 3 I, ro U.S.C. $\$ 83 I$ (1970).

251 U.C.M.J., art. 32 , ro U.S.C. $\$ 832$ (1970).

282 U.C.M.J., art. 138, ro U.S.C. $\$ 938$ (1970). The Court of Military Appeals has recognized Article I3 8 as a proper means to question the legality of pretrial or post-trial confinement. Dale v. United Statcs, I9 U.S.C.M.A. 254, 4 I C.M.R. 254 (1970); Walker v. United States, 19 U.S.C.M.A. 247, 41 C.M.R. 247 (1970). However, the armed services apparently take the position that, except as to confinement, the Article does not concern matters involving discipline. See OpJAGAF 1972/11I (Oct. 17, 1972); OpJAGAF 1972/53 (Apr. 26, 1972).

${ }_{258}^{28 . C . M . J ., ~ a r t . ~ I 5(a), ~ t o ~ U . S . C . ~ \$ ~ 815 ~(a) ~(1970) . ~}$

${ }^{254}$ U.C.M.J., art. 20 , 10 U.S.C. $\$ 820$ (1970).
} 
special or general court-martial the accused may, with the military judge's consent, waive trial by the military jury and elect to be tried and sentenced by the judge alone. ${ }^{255}$ An enlisted accused may require that the jury of a special or general courtmartial which tries him contain at least one-third enlisted personnel at all times. ${ }^{256}$ The cieation of these various rights and the customary requirement that a waiver of the rights be knowing and intelligent has necessitated the increasing availability of military lawyers to advise accused persons concerning the alternatives available to them.

In addition to the more obvious limitations that the Uniform Code has placed on a commander's discretion, there are others which are less visible. For example, if a commander fails, under some circumstances, to assign a military judge or a legally qualified military defense counsel to a special court-martial, he must attach to the record of trial his explanation of the necessities which required the use of laymen. ${ }^{257}$ Similarly, if he fails to accept the post-trial recommendation of his staff judge advocate, the commander must attach to the record the reasons for this disagreement. ${ }^{258}$ The necessity of the explanation and the possibility that it might later be scrutinized judicially and found wanting, undoubtedly induce considerable reluctance in a commander to take the action that might appear to be within his discretion.

A commander still retains the authority to refer cases to a special court-martial that consists only of lay members and has no military judge. ${ }^{259}$ However, by limiting the punishment which such a court-martial could impose and by providing for the presence of legally-trained defense counsel in almost all special courts-martial, ${ }^{260}$ Congress has created a situation where a commander would seldom feel that it was practical to appoint a special court-martial that had no military judge. Similarly, while the Uniform Code does not require that the trial counsel-prosecutor-in special courts-martial must be an attorney, the provision that legally-trained defense counsel be provided in such courts compels the commander to appoint a lawyer to prosecute in order to avoid a mismatch of legal skills that might be disastrous for the Government's case.

Just as the alternatives available to a commander may be less meaningful than at first appears, so to, the choices available for an accused may have some restrictions not at first apparent. For example, the opportunity of an accused to elect trial by an enlisted court-martial is diminished in significance by the right of the commander to appoint as enlisted members senior non-commissioned officers who usually would be oriented to the prosecution. ${ }^{261}$

Since I95I when the Uniform Code of Military Justice took effect, there have

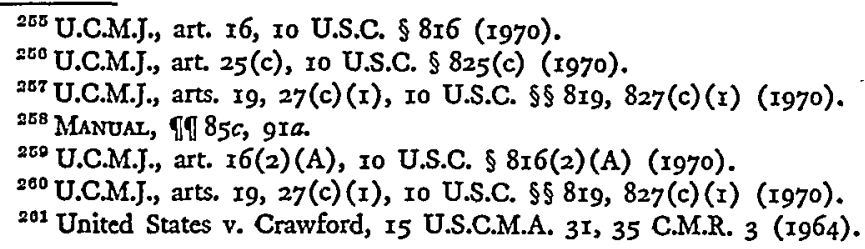


emerged many new limitations on the discretion of commanders in administering military justice. Many of those limitations were imposed by the decisions of the Court of Military Appeals, a civilian tribunal created by the Code. For example, this court expanded pretrial safeguards, ${ }^{202}$ helped transform the "law officer" of a general court-martial into a "military judge,"263 required detailed instructions concerning the evidence and the offenses, ${ }^{264}$ gave new meaning to appellate review, ${ }^{205}$ and created extraordinary remedies. ${ }^{268}$ The court deprived the Manual for CourtsMartial, prescribed by the President, of its stature as a "bible" for the military lawyer. ${ }^{267}$

The various military departments promulgated regulations and developed policies which limited the discretion of commanders in the field. For example, the Army, Navy, and Marine Corps, while authorizing a commander to accept or decline a proposed negotiated guilty plea, have required that the bargain be embodied in a written pretrial agreement, so that it is visible and will not be subject to misunderstanding concerning the terms.

The Army's initiative in developing a trial judiciary-law officers who were allowed to specialize in military justice and were insulated from possible command influence in the field-has had a major impact on military justice. Together with the decisions of the Court of Military Appeals, this innovation, swiftly adopted by the Navy and Marine Corps, led to congressional provision for "military judges" in both general and special courts-martial. ${ }^{208}$ In turn, creation of this new positionand the prestige, independence, and power provided for it-has had the practical effect of reducing the discretion available to military commanders in administering military justice. Various types of decisions previously made by commanders are gradually being transferred to military judges. In a similar manner, the Army has now provided for "military magistrates," who are authorized to make determinations concerning searches and seizures and pretrial confinement that previously were entrusted solely to commanders. ${ }^{269}$

The enactment of the Military Justice Act of 1968 reflected a congressional intent

\footnotetext{
${ }^{202}$ See, e.g., United States v. Tempia, r6 U.S.C.M.A. 629, 36 C.M.R. 249 (1967); United States v. Wilson, 2 U.S.C.M.A. 248, 8 C.M.R. 48 (r953).

${ }^{263}$ For different opinions concerning this transformation, see Quinn, Courts-Martial Practice: $A$ View from the Top, 22 HAsr. L.J. 20r, 208-10 (I97I); Miller, Who Made the Law Officer a "Federal Iudge"?, 4 MrL. L. REv. 39 (I959).

204 See, e.g., United States v. Amie, 7 U.S.C.M.A. 514, 22 C.M.R. 304 (1957); United States v. Clay, I U.S.C.M.A. 74, I C.M.R. 74 (I95I).

${ }^{206}$ See, e.g., United States v. Chandler, 22 U.S.C.M.A. 73, 46 C.M.R. 73 (1972); United States v. Massey, 5 U.S.C.M.A. 514, I8 C.M.R. 138 (I955); United States v. Coulter, 3 U.S.C.M.A. 657, r4 C.M.R. 75 (1954).

${ }_{200}$ See, e.g., United States v. Synder, I8 U.S.C.M.A. 480, 40 C.M.R. I92 (I969); United States v. Bevilacqua, 18 U.S.C.M.A. Io, 39 C.M.R. Io (r968); Everett, supra note 235.

${ }^{207}$ As to the change in the court's attitude toward the Manual, compare United States v. Hemp, I U.S.C.M.A. 280, 3 C.M.R. I4 (1952), with United States v. Rinehart, 8 U.S.C.M.A. I45, 23 C.M.R. 369 (1957). See also Quinn, stupra note 263 , at 203-08.

${ }_{208}$ U.C.M.J., art. 26, to U.S.C. $\$ 826$ (1970).

${ }^{200}$ See I97I ANNUAI REPORT, stipta note 3 , at 3, 2I:
} 
to curtail in certain ways the discretion of military commanders. Thus, the strengthening of prohibitions on command influence was intended to remove a commander's discretion to take certain action that might influence the outcome of a trial by court-martial. ${ }^{270}$ The requirement that legally-trained counsel be assigned in special courts-martial was designed to lessen significantly the scope of the commander's discretion in appointing defense counsel for such courts. ${ }^{271}$

However, the Uniform Code and the rg68 amendments thereof limited commanders' discretion in one way that probably was not fully appreciated. By making military justice far more technical and complicated, Congress-together with the Court of Military Appeals-has created a situation where a commander feels far more dependent on his legal advisers. At least as to serious offenses, the alternatives for commanders have become so much more complicated that, regardless of the discretion provided them by statute, they can hardly feel much confidence in disregarding recommendations of their legal advisers. In short, for purposes of military justice, as in many other areas, the military commander has become much more dependent on the technician; and so, in practical effect, his discretion has been reduced.

Another result of the increasing complexity of military justice is the use by commanders of alternatives other than court-martial in maintaining discipline. Assignments of duty, promotions or demotions, administrative discharge, release from active duty or call to duty have been among the means available. Use of these alternatives was often more attractive because of a traditional judicial reluctance to review assignments of military duties and similar matters. ${ }^{272}$ However, in some instances the federal courts found authority to correct abuses of discretion involved in disciplinary measures other than trial by court-martial. Especially with respect to administrative discharges, ${ }^{273}$ the courts have acted to limit the discretion of military commanders-sometimes by finding violations of the regulations of the military department involved.

Of much greater impact in limiting military discretion was the Supreme Court's decision in $O^{\prime}$ Callahan v. Parker, ${ }^{274}$ which ruled that-subject to some possible exceptions-even offenses committed by servicemen could not be tried by courtmartial unless those offenses were service-connected. The rationale of $O^{\prime}$ Callahan is especially noteworthy since it transcends questions of court-martial jurisdiction and concerns the substantive power of military commanders to regulate the conduct of their personnel in matters not clearly service-connected.

From one direction or another, further inroads may be anticipated on the discretion of military commanders in administering military justice. Probably the

\footnotetext{
${ }^{270}$ U.C.M.J., art. 37 , 10 U.S.C. $\$ 837$ (1970).

271 U.C.M.J., art. $27(\mathrm{c})(\mathrm{I})$, 10 U.S.C. $\$ 827$ (c)(I) (1970).

${ }^{272}$ Orloff v. Willoughby, 345 U.S. 83 (1953).

${ }^{273}$ Harmon v. Brucker, 355 U.S. 579 (1958); Everett, supra note 104, at 4r.

${ }^{274} 395$ U.S. 258 ( 1969 ).
} 
summary court-martial will disappear from the scene-at least in its present form. ${ }^{276}$ The role and power of the military judge will increase, and with it will come a diminution of the authority of military commanders. It seems likely that soon the military judge will be empowered to issue all the writs authorized by the All Writs Act, ${ }^{276}$ will be ruling on search and arrest questions and the issuance of warrants, will be granting releases from pretrial and post-trial confinement, and will become even more involved in the sentencing process, even without specific waiver by the accused of his right to be tried by military jury.

The incessant complaints about composition and selection of courts-martial may soon diminish sharply as changes occur in the procedures for selecting court members. Greater use of random selection of such members seems increasingly probable, but the high percentage of waivers of trial by jury may reduce the importance of the entire issue. Furthermore, recent Supreme Court decisions which have altered prevailing conceptions of the constitutional right to "trial by jury" tend to reduce criticisms that military justice deprives an accused of his right to jury trial.

Whatever the commander's role may become in the selection of court-martial members, he will probably retain a major role in determining which offenses are tried by court-martial. Thus, he will continue to share in that discretion usually enjoyed by prosecuting attorneys. His role in the process of appellate review may become more limited-partly in response to the more technical nature of the issues presented during this review and partly because of the desirability of transferring clemency and rehabilitation decisions to experts in penology and corrections.

In response to complaints in Congress and elsewhere that racial discrimination occurs in the administration of military justice, a task force established by the Department of Defense has recently been studying military justice. Its report deals both with intentional discrimination ${ }^{277}$ and systemic discrimination; ${ }^{278}$ and the recommendations extend to preservice educational factors, equal opportunity programs, job assignments and testing, regulation of personal appearance, updating racial and ethnic identity codes, and administrative discharges. As to the military justice system, the Task Force Report recommends various changes in nonjudicial punishment, ${ }^{279}$ decreased use of summary courts-martial, ${ }^{280}$ increased stature for military judges and counsel, random selection of court members, reduction of the convening

\footnotetext{
${ }^{275}$ Over the years there have been many recommendations for abolition of summary courts-martial. Now, as a result of the decision in Argersinger v. Hamlin, 407 U.S. 25 (1972), their continued use may be unfeasible. See note 203, supra.

27628 U.S.C. $\$ 165 \mathrm{r}$ (a) (1970).

${ }^{277}$ The Task Force has defined intentional discrimination as "a policy of an authority-especially in the context of our study, a military authority-or action of an individual or group of individuals which is intended to have a negative effect on minority individuals or groups without having such an effect on others." TASK FORCE REPORT I8-rg.

${ }^{278}$ Systemic discrimination has been defined as "policies or practices which appear to be neutral in their effect on minority individuals or groups but which have the effect of disproportionately impacting upon them in harmful or negative ways." .Id.

279 Supra note 105.,

${ }^{280}$ Supra note 227. Summary courts-martial have very minimal use currently in the Air Force.
} 
authority's role in appellate review, codification of offenses currently tried under Article $134,{ }^{281}$ and better military justice training. ${ }^{282}$ Aside from the recommendations concerning nonjudicial punishment, as to which the effects are hard to predict, the Report does not seem to call for drastic revision in the military justice system.

Perhaps-but not probably-some new task force or investigative group will bring to light some abuses not previously suspected. In that event drastic new restrictions may be imposed administratively or legislatively on the discretion of commanders in maintaining discipline and punishing crime.

For example, jurisdiction of all offenses committed within the United States by service personnel might be transferred from courts-martial to federal district courts, so that the United States Attorney, rather than a military commander, would make the decision as to which offenses would be prosecuted. And even as to offenses committed overseas, greater civilian influence might be provided-perhaps replacing the "military judges" with civilian judges.

Up to this point, the case for new major changes in military justice does not seem to have been proved. Indeed, Congress will probably wish to allow further opportunity for evaluation of the existing system, as substantially amended by the Military Justice Act of 5968 and by various innovations and pilot programs that have been initiated by the armed services. Thus, for the foreseeable future it seems likely that military commanders will continue to enjoy broad discretion in the administration of justice.

\footnotetext{
${ }^{281}$ This specificity has also been recommended by the Court of Military Appeals and the Judge Advocates General. I97I ANNUAL REPORT, supra note 3, at I-2.

${ }^{282}$ The Task Force Report also has recommendations concerning Status of Forces agreements. Supra note 125 .
} 


\section{DUKE LAW JOURNAL}

A law review edited by students of Duke University School of Law and devoted to a discussion of legal topics of current interest. Subscription Rate: $\$ \mathrm{I} 2.00$ (six issues).

\section{VoLUME I972 No. 5 INCLUDES:}

A Tribute to Dean Elvin R. Latty. Norman D. Lattin

Close Corporation Legislation: A Survey and an Evaluation. F. Hodge O'Neal

A Behavioral Analysis of Directors'

Liability for Negligence. Alfred F. Conard The Minority's Duty of Loyalty in Close Corporations. .J.A.C. Hetherington Liability of Corporate Shares to Legal Process Pierre R. Loiseaux

Comment: SEC Disciplinary Rules and the Federal Securities Laws: The Regulation, Role and Responsibilities of the Attorney

Book Review: The University as a Shareholder and Investor in Publicly Held Corporations: A Comment on "The Ethical Investor".....................Robert H. Mundheim

Volume I972 No. 6 INCLUdes:

Latty and "Corporations" in the Academy George T. Frampton The Annual Report: A Prime Disclosure Document.....A. A. Sommer, Jr. Limitations on Civil Liability Under Rule rob $5 . . . . . . .$. David S. Ruder Neil S. Cross

New Problems in Indemnifying and Insuring Directors:

Protection Against Liability Under the

Federal Securities Laws Joseph W. Bishop, Jr.

The Impact of Class Actions on Corporate and Securities Law. Mordecai Rosenfeld

Reflections on the Practical Aspects of

"The Sale of Corporate Control". William N. Snell

Address Subscription and Inquiries to the Research and Managing Editor

DUKE LAW JOURNAL

Duke University School of Law Durham, North Carolina 27706 